\title{
Synthesis and Biological Evaluation of a Teixobactin Analogue
}

Yahya E. Jad, ${ }^{1}$ Gerardo A. Acosta, ${ }^{2,3}$ Tricia Naicker, ${ }^{1}$ Melissa Ramtahal, ${ }^{1}$ Ayman ElFaham $^{4,5}$ Thavendran Govender, ${ }^{1}$ Hendrik G. Kruger, ${ }^{1}$ Beatriz G. de la Torre, ${ }^{1}$ and Fernando Albericio ${ }^{* 1,2,3,5,6,7}$

${ }^{1}$ Catalysis and Peptide Research Unit, School of Health Sciences, University of KwaZulu-Natal, Durban 4001, South Africa;

${ }^{2}$ Institute for Research in Biomedicine-Barcelona,08028-Barcelona, Spain; ${ }^{3}$ CIBER-BBN, Networking Centre on Bioengineering, Biomaterials and Nanomedicine, Barcelona Science Park, 08028-Barcelona, Spain; ${ }^{4}$ Department of Chemistry, Faculty of Science, Alexandria University P.O. Box 426, Ibrahimia, Alexandria 21321, Egypt; ${ }^{5}$ Department of Chemistry, College of Science, King Saud University P.O. Box 2455,Riyadh11451, Saudi Arabia; ${ }^{6}$ School of Chemistry and Physics, University of KwaZulu-Natal, Durban 4001, South Africa; ${ }^{7}$ Department of Organic Chemistry, University of Barcelona, 08028Barcelona, Spain.

Author to whom correspondence should be addressed; E-Mails: albericio@irbbarcelona.org (F.A.)

\section{Materials}

All reagents and solvents were obtained from commercial suppliers and were used without further purification unless otherwise stated. NMR spectra $\left({ }^{1} \mathrm{H}\right.$ NMR and ${ }^{13} \mathrm{C}$ NMR) were recorded on a Bruker AVANCE III $400 \mathrm{MHz}$ spectrometer. Chemical shift values are expressed in ppm. Analytical HPLC was performed on an Agilent 1100 system, and Chemstation software was used for data processing. Buffer A: $0.1 \%$ trifluoroacetic acid in $\mathrm{H}_{2} \mathrm{O}$; buffer B: $0.1 \%$ trifluoroacetic acid in $\mathrm{CH}_{3} \mathrm{CN}$. LC-MS was performed on a Shimadzu 2020 UFLC-MS using an YMC-Triart $\mathrm{C}_{18}(5 \mu \mathrm{m}, 4.6 \times 150$ $\mathrm{mm}$ ) column and data processing was carried out by LabSolution software. Buffer A: 0.1 $\%$ formic acid in $\mathrm{H}_{2} \mathrm{O}$; buffer B: $0.1 \%$ formic acid in $\mathrm{CH}_{3} \mathrm{CN}$. Crude peptide was purified on Shimadzu LC-8A preparative HPLC using a Phenomenex $\operatorname{LumaC}_{18}(2)$ column $(10 \mu \mathrm{m}, 21.1 \times 250 \mathrm{~mm})$. High resolution mass spectrometry (HRMS) was performed using a Bruker ESI-QTOF mass spectrometer in positive mode.

For NMR of 1: ${ }^{1} \mathrm{H}$ and ${ }^{13} \mathrm{C}$ experiments were recorded on Bruker AVANCE III $600 \mathrm{MHz}$ instrument operating at $30^{\circ} \mathrm{C}$ according to the standard Bruker library, using 16 and 9600 scans, respectively. 2D homonuclear COSY experiments and heteronuclear HSQC and HMBC experiments were recorded according to the standard Bruker library with 8 and 512; 8 and 256; and 16 and 512 scans and number of complex points in f1 dimension, respectively. 


\section{Experimental section}

\section{Synthesis of Alloc amino acids ${ }^{1}$}

A solution of allyloxycarbonyloxysuccinimide (Alloc-OSu, 2.19 g, 11 mmol, 1.1 equiv) in THF $(30 \mathrm{ml})$ was added to a solution of H-L-Ile-OH or H-L-Arg(Pbf)-OH (10 mmol, 1 equiv) and potassium carbonate $(2.76 \mathrm{~g}, 20 \mathrm{mmol}, 2$ equiv) in water $(30 \mathrm{~mL})$. The mixture was stirred for $1 \mathrm{~h}$ at $0{ }^{\circ} \mathrm{C}$ and overnight at room temperature. Then, the solution was concentrated under reduced to approximately $30 \mathrm{~mL}$. This solution was washed withdiethylether $(3 \times 30 \mathrm{~mL})$. The aqeuous fraction was then acidified by $37 \%$ hydrochloric acid to congo red litmus paperand extracted withdichloromethane $(4 \times 50$ $\mathrm{ml})$. The combined halogenated layers were dried $\left(\mathrm{MgSO}_{4}\right)$ and evaporatedto crude compound which was purified by column chromatography.

Alloc-L-Ile-OH: purified by column chromatography (ethyl acetate/n-hexane,2:1) and it was obtained as oily product in $86 \%$ yield $(1.8 \mathrm{~g}) .{ }^{1} \mathrm{H}$ NMR $(400 \mathrm{MHz}, \mathrm{CDCl} 3): 0.95$ $\left(3 \mathrm{H}, \mathrm{t}, J=7.2 \mathrm{~Hz}, \mathrm{CH}_{3}\right), 0.99\left(2 \mathrm{H}, \mathrm{t}, J=6.8 \mathrm{~Hz}, \mathrm{CH}_{3}\right), 1.22(1 \mathrm{H}, \mathrm{m}, \mathrm{CH} \underline{\mathrm{H}}), 1.49(1 \mathrm{H}, \mathrm{m}$, CㅂH), $1.95(1 \mathrm{H}, \mathrm{m}, \mathrm{CH}), 4.37(1 \mathrm{H}, \mathrm{dd}, J=8.8$ and $4.4 \mathrm{~Hz}, \mathrm{CH}), 4.60(2 \mathrm{H}, \mathrm{d}, J=5.6 \mathrm{~Hz}$, $\left.\mathrm{CH}_{2}\right), 5.24(1 \mathrm{H}, \mathrm{m}, \mathrm{CH}), 5.31(1 \mathrm{H}, \mathrm{d}, \mathrm{NH}), 5.33(1 \mathrm{H}, \mathrm{m}, \mathrm{CH}), 5.92(1 \mathrm{H}, \mathrm{m}, \mathrm{CH}),{ }^{13} \mathrm{C}$ NMR: $11.6,15.5,24.8,37.7,58.2,66.0,118.0,132.5,156.2,176.7$.

${ }^{1} \mathrm{H}$ NMR spectra of Alloc-L-Ile-OH

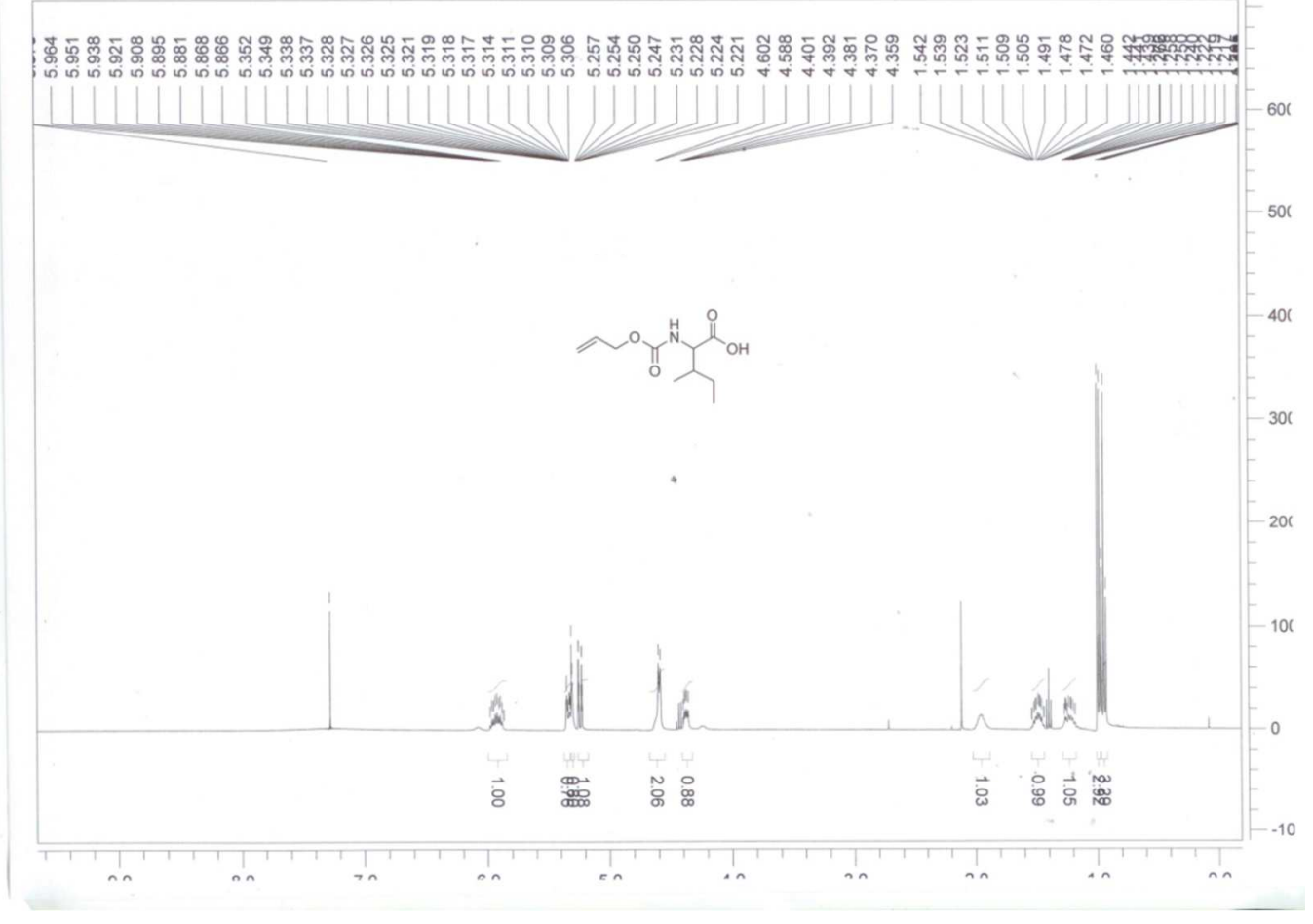


${ }^{13} \mathrm{C}$ NMR spectra of Alloc-L-Ile-OH

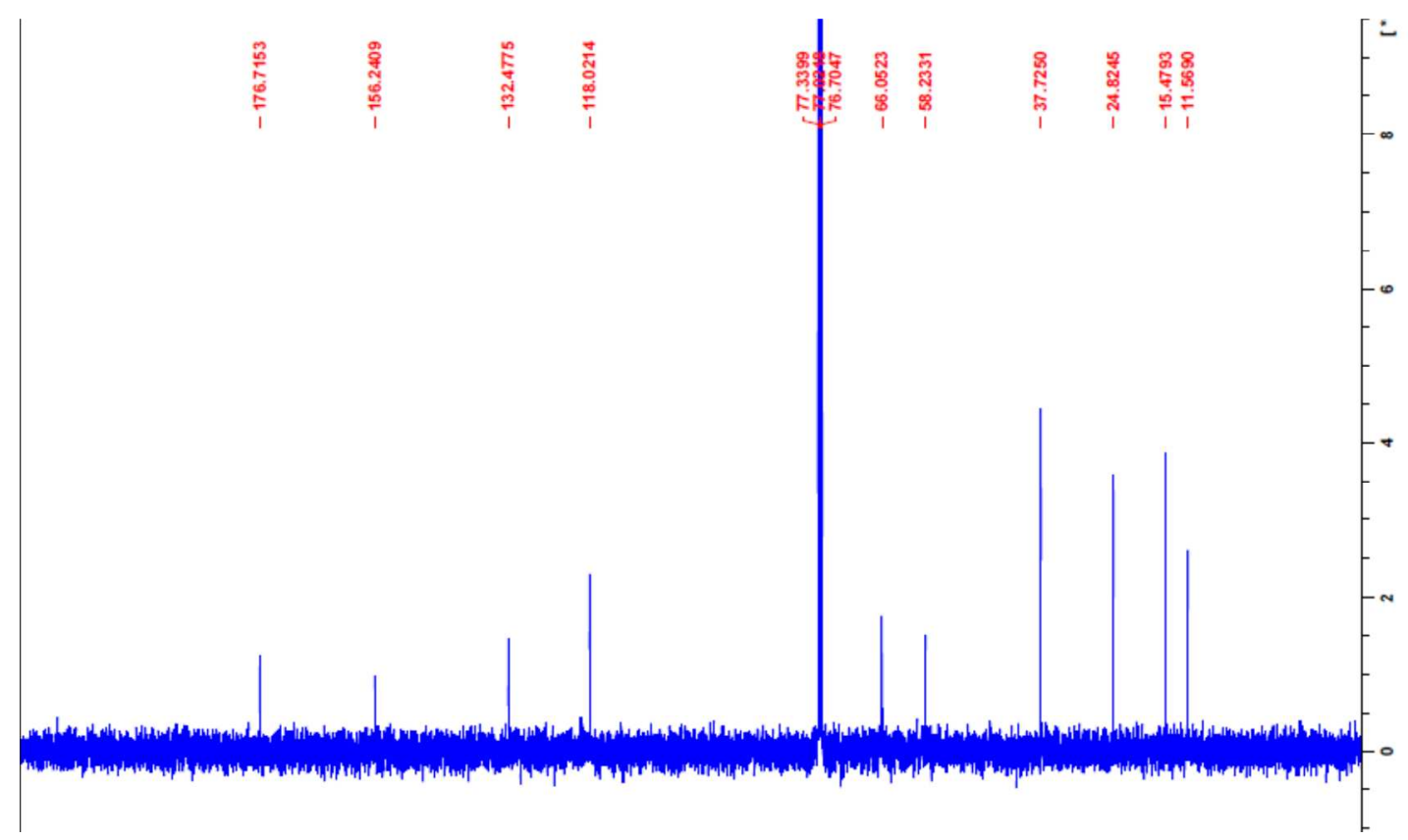

Alloc-L-Arg(Pbf)-OH: the product was obtained in $93 \%$ yield (4.75 g) and it is pure enough for SPPS without further purification. ${ }^{1} \mathrm{H}$ NMR (400 MHz, $\mathrm{CDCl}_{3}$ and DMSO$\left.\mathrm{d}_{6}\right): 0.93\left(6 \mathrm{H}, \mathrm{s}, 2 \mathrm{CH}_{3}\right), 1.03\left(2 \mathrm{H}, \mathrm{m}, \mathrm{CH}_{2}\right), 1.13(1 \mathrm{H}, \mathrm{m}, \mathrm{CH} \underline{\mathrm{H}}), 1.27(1 \mathrm{H}, \mathrm{m}, \mathrm{CH} \underline{\mathrm{H}}), 1.54$

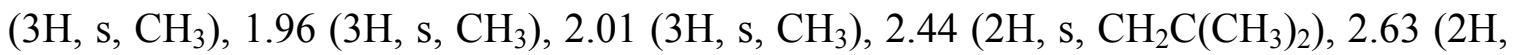
s, $\left.\mathrm{CH}_{2} \mathrm{NH}\right), 3.55(1 \mathrm{H}, \mathrm{m}, \mathrm{NH}), 4.00\left(2 \mathrm{H}, \mathrm{d}, J=3.6 \mathrm{~Hz}, \mathrm{Alloc} \mathrm{CH}_{2}\right), 4.36(1 \mathrm{H}, \mathrm{dd}, J=0.8$ and $6.8 \mathrm{~Hz}$, Alloc $\mathrm{CH}), 4.77(1 \mathrm{H}, \mathrm{d}, J=11.2 \mathrm{~Hz}$,Alloc $\mathrm{CH}), 5.38(1 \mathrm{H}, \mathrm{m}$, Alloc $\mathrm{CH}), 5.96$ $(1 \mathrm{H}, \mathrm{s}, \mathrm{NH}), 6.07(1 \mathrm{H}, \mathrm{s}, \mathrm{NH}), 6.18(1 \mathrm{H}, \mathrm{s}, \mathrm{COOH}),{ }^{13} \mathrm{C} \mathrm{NMR}: 12.4,17.8,19.2,25.8$, 28.6, 29.1, 43.2, 53.9, 54.1, 65.3, 86.4, 117.0, 117.4, 124.5, 132.1, 133.2, 138.0, 156.4, $158.3,174.1$. 


\section{${ }^{1}$ H NMR spectra of Alloc-L-Arg(Pbf)-OH}
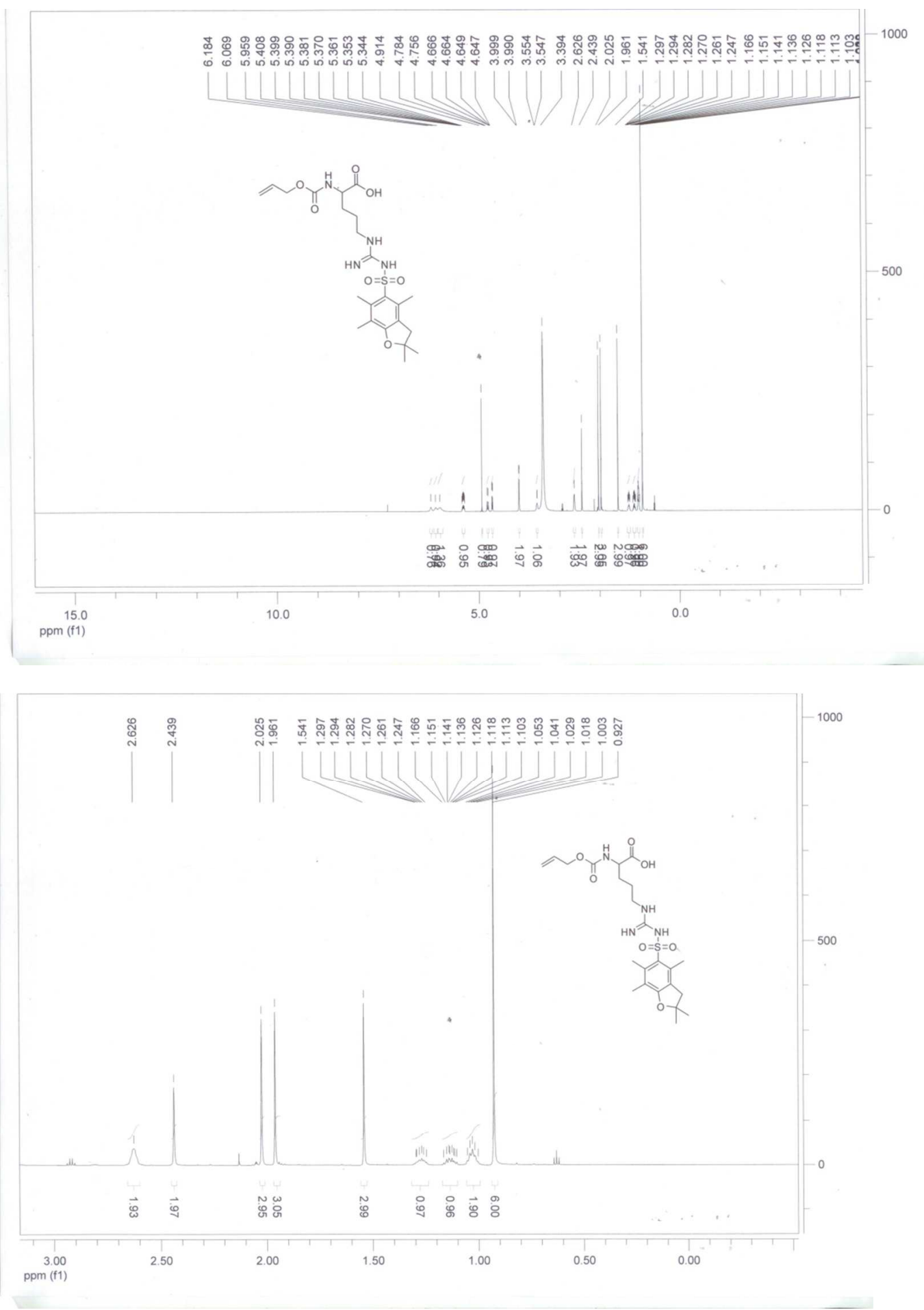


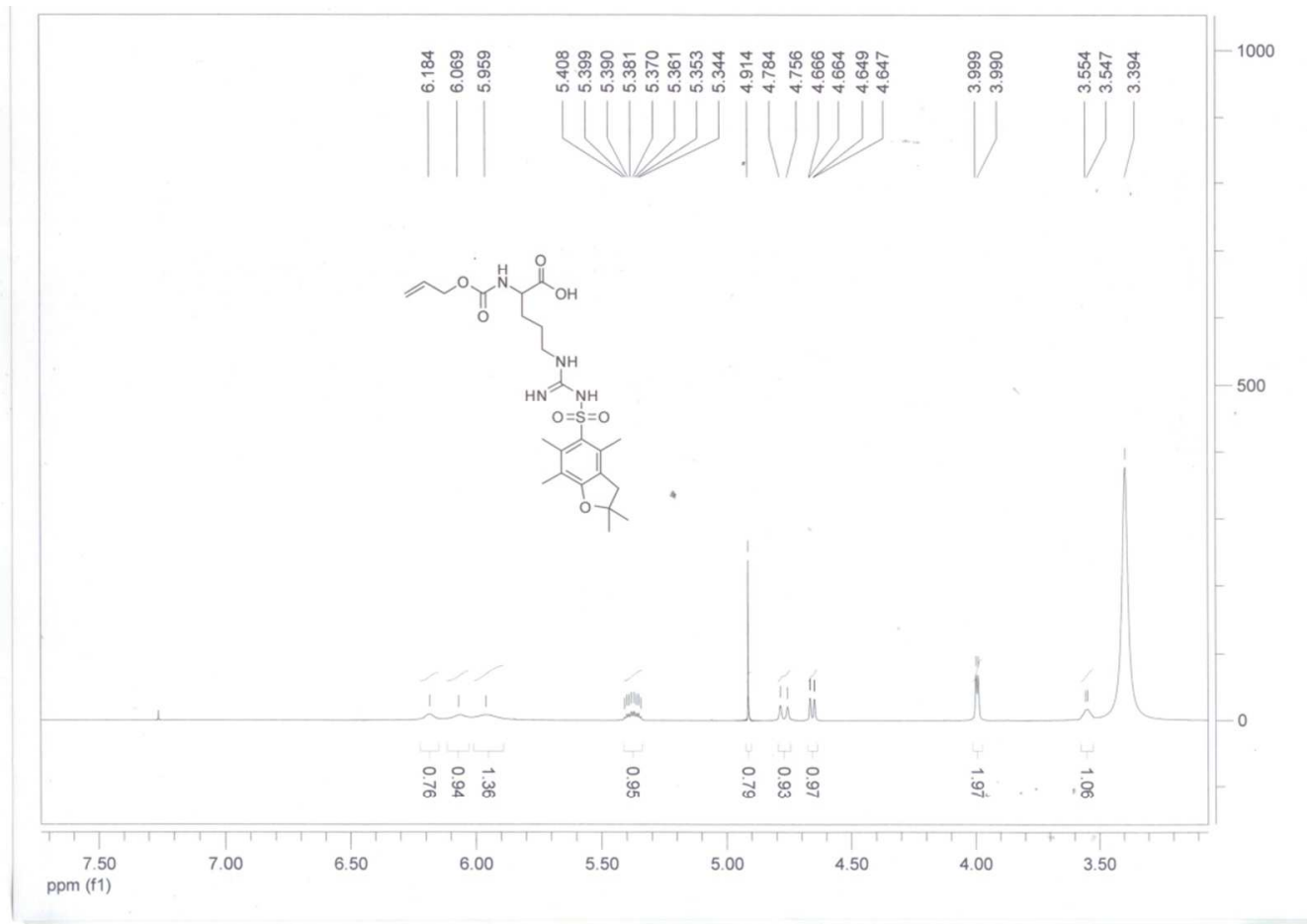

${ }^{13} \mathrm{C}$ NMR spectra of Alloc-L-Arg(Pbf)-OH

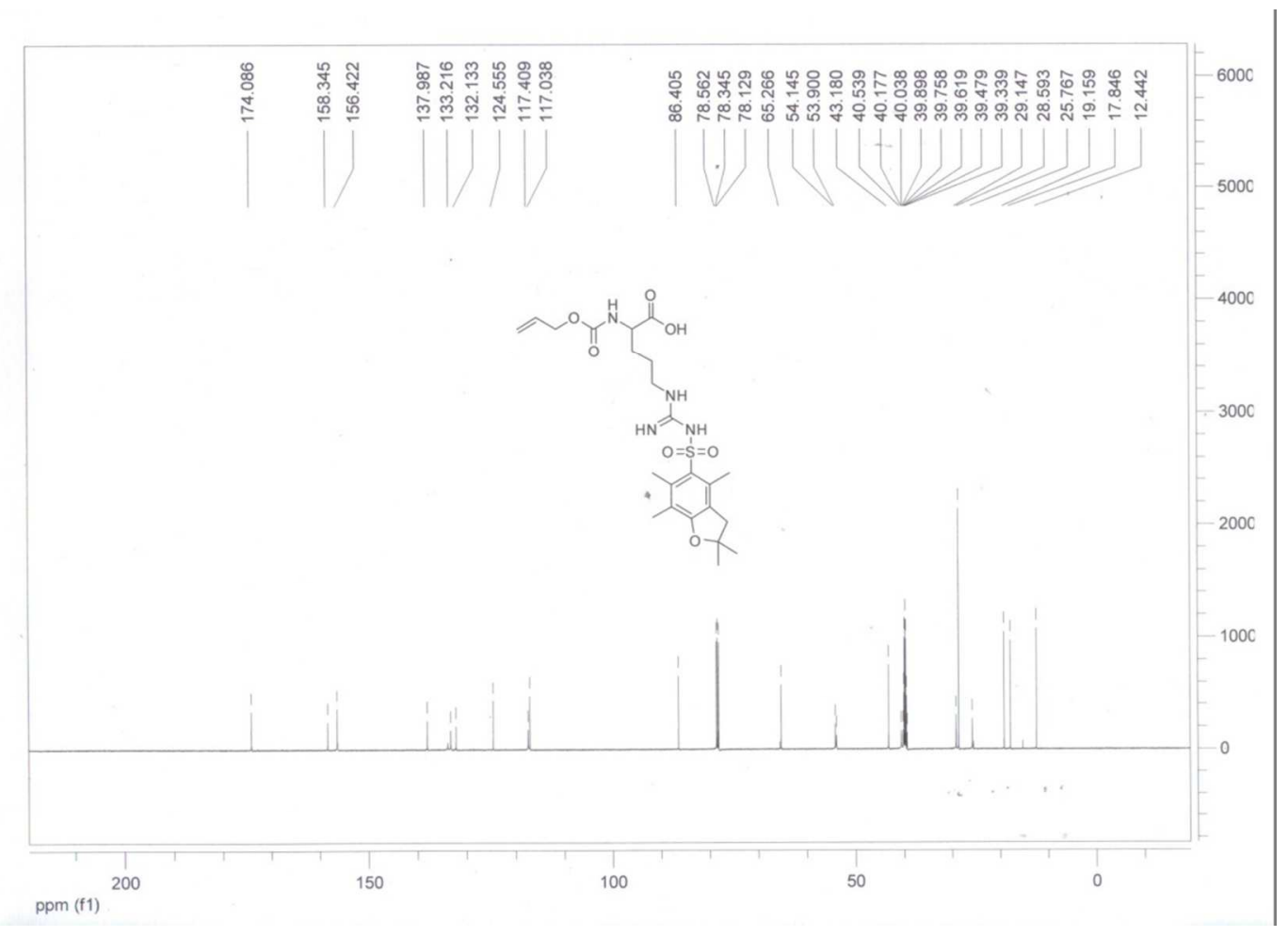




\section{Synthesis of L-Arg analogue of teixobactin}

\section{a) Synthesis of tetrapeptide 6}

$166 \mathrm{mg}$ of 2-Cl-Trt resin $\left(1.69 \mathrm{mmolg}^{-1}\right)$ was placed in a $10 \mathrm{~mL}$ polypropylene syringe fitted with a polyethylene filter disc and then was preactivated by $10 \% \mathrm{SOCl}_{2}$ in $\mathrm{DCM}$ for $12 \mathrm{~h}$. The resin was washed several times with DCM. Then, it washed with DMF $(2 \times$ $10 \mathrm{~mL}, 1 \mathrm{~min})$ and DCM $(2 \times 10 \mathrm{~mL}, 1 \mathrm{~min})$ followed by adding the first amino acid Fmoc-L-Ala-OH (31 mg, $0.1 \mathrm{mmol})$ and DIEA ( $174 \mu \mathrm{L}, 1 \mathrm{mmol}, 10$ equiv) in $0.5 \mathrm{~mL}$ DCM and shacked for $1 \mathrm{~h}$. Then $100 \mu \mathrm{L}$ was added and shacked for $30 \mathrm{~min}$. Then the resin was washed with DMF $(2 \times 10 \mathrm{~mL}, 1 \mathrm{~min})$, DCM $(2 \times 10 \mathrm{~mL}, 1 \mathrm{~min})$, isopropanol $(2 \times 10 \mathrm{~mL}, 1 \mathrm{~min})$, DCM $(2 \times 10 \mathrm{~mL}, 1 \mathrm{~min})$ and DMF $(2 \times 10 \mathrm{~mL}, 1 \mathrm{~min})$. Then, Fmoc removal was achieved by $20 \%$ piperidine in DMF $(2 \times 10 \mathrm{~mL}, 5 \mathrm{~min})$. Then, the next amino acids were added by using the following coupling condition:

For coupling:Fmoc-AA-OH/HATU/DIEA (3:3:6) in $1 \mathrm{~mL}$ DMF for $30 \mathrm{~min}$

For Fmocremoval: $20 \%$ piperidine in DMF $(2 \times 10 \mathrm{~mL}, 5 \mathrm{~min})$

Washing: DMF $(2 \times 10 \mathrm{~mL}, 1 \mathrm{~min}), \mathrm{DCM}(2 \times 10 \mathrm{~mL}, 1 \mathrm{~min})$ and DMF $(2 \times 10 \mathrm{~mL}, 1$ $\min )$

Until getting tetrapeptide 6 (Fmoc-L-Ile-L-Ser-D-Thr-L-Ala-OH), mini-cleavage was performed in order to monitor the esterification step

HPLC chromatogram of Fmoc-L-Ile-L-Ser-D-Thr-L-Ala-OH 6:

A linear gradient of $5-95 \% \mathrm{CH}_{3} \mathrm{CN} / \mathrm{H}_{2} \mathrm{O}$ and $0.1 \%$ TFA over 15 min was applied, with a flow rate of $1.0 \mathrm{~mL} / \mathrm{min}$ and detection at $220 \mathrm{~nm}$ using a Phenomenex $\mathrm{C}_{18}(3 \mu \mathrm{m}, 4.6 \times$ $50 \mathrm{~mm})$ column. $t_{R}($ tetrapeptide $\mathbf{6})=8.7 \mathrm{~min}$, purity $=85.7 \%$

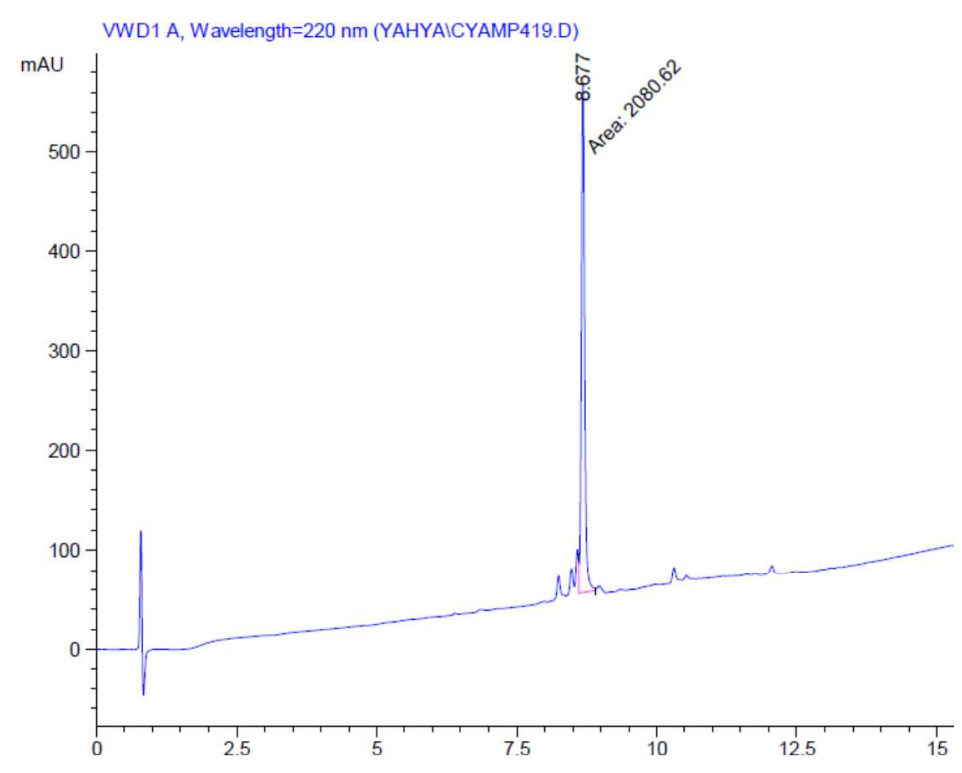


MS

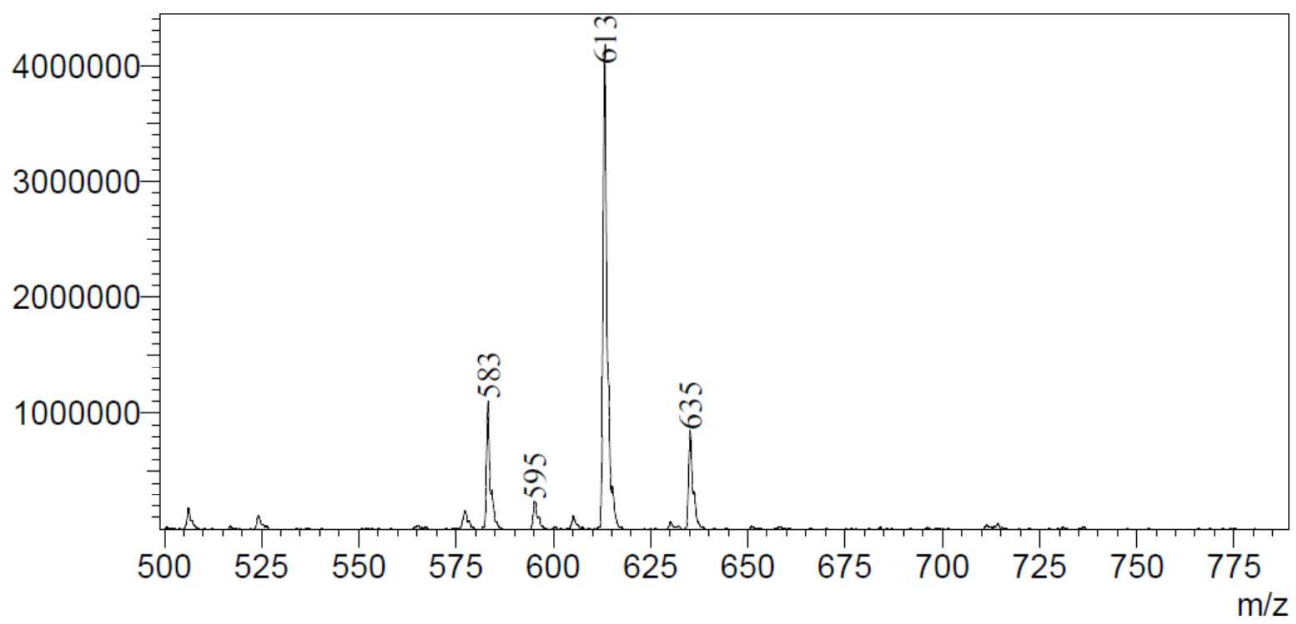

\section{b) Ester-bond formation 7}

Initially, the ester bond formation was achieved by using the following condition: AllocL-Ile-OH (215 mg, $1 \mathrm{mmol}, 10$ equiv), DIC ( $77 \mu \mathrm{L}, 0.5 \mathrm{mmol}, 5$ equiv) and DMAP (12 $\mathrm{mg}, 0.1 \mathrm{mmol}, 1$ equiv) in DCM/DMF $(8: 2)(2 \times 24 \mathrm{~h})$. However, after finishing the synthesis, no increasing on the resin's weight was observed. Therefore, the filtrate of the esterification reaction was checked on the second trail and the masses corresponding to tetrapeptide 6 and pentadepsipeptide 7 were observed.

\section{MS}

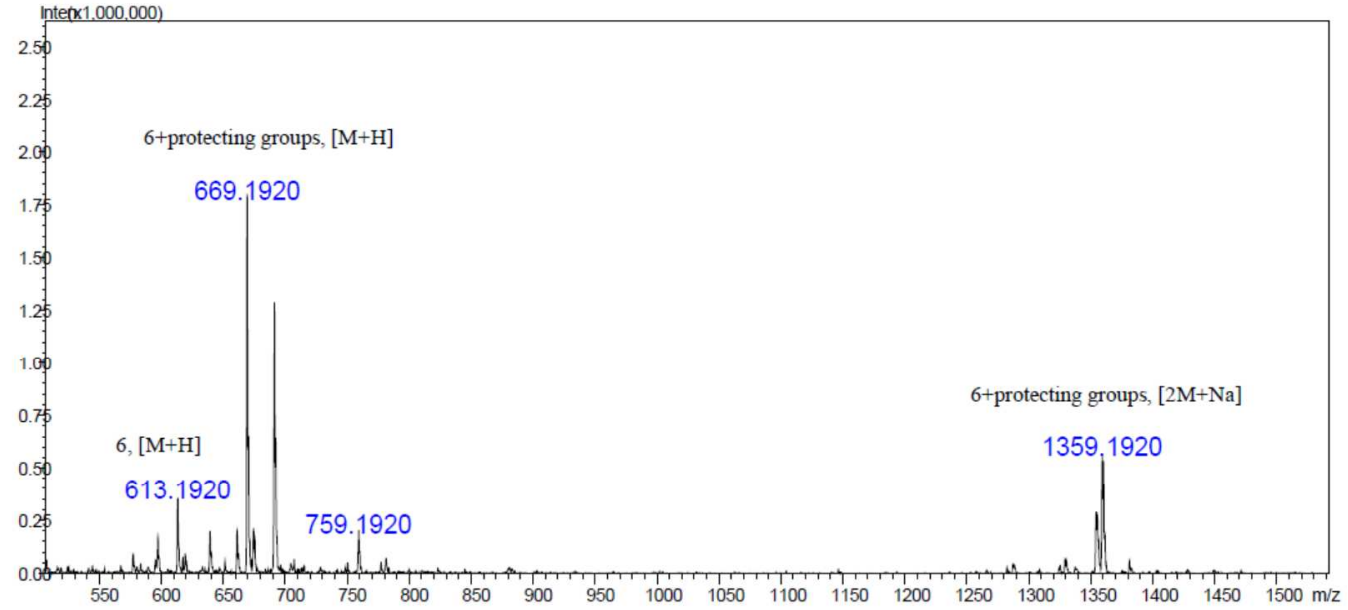




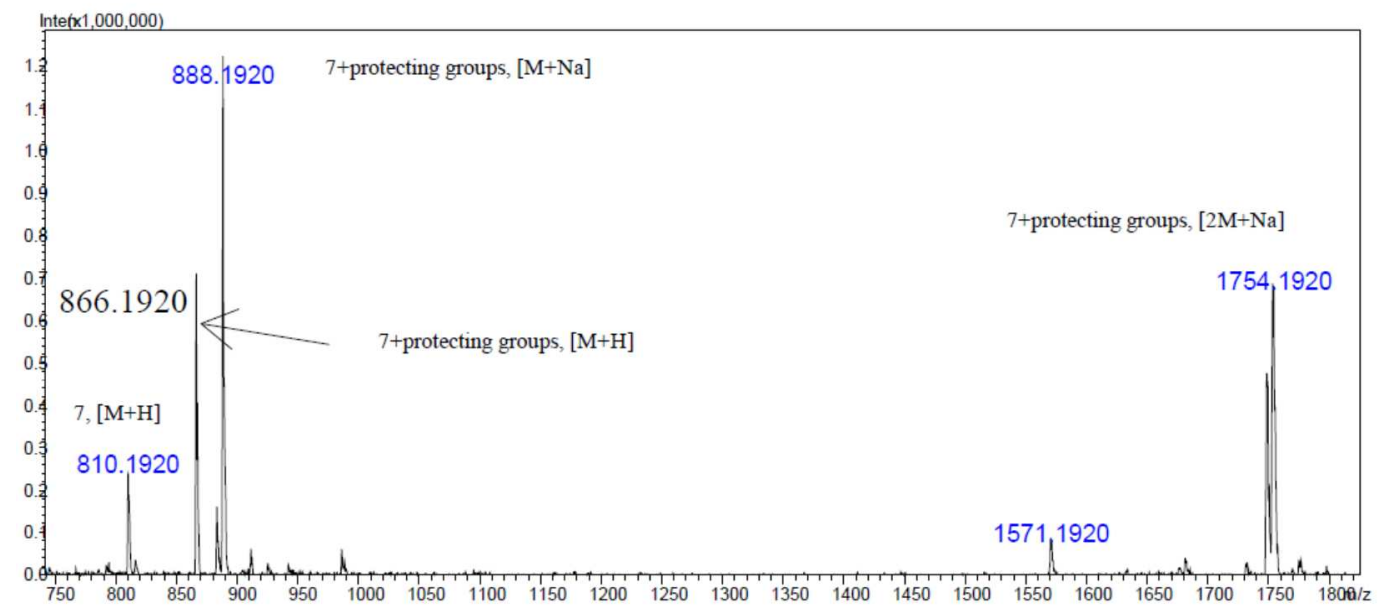

Therefore, the following condition was utilized for formation of ester bond: Alloc-L-Ile$\mathrm{OH}$ (107 mg, $0.5 \mathrm{mmol}, 5$ equiv), DIC ( $77 \mu \mathrm{L}, 0.5 \mathrm{mmol}, 5$ equiv), pyridine ( $38 \mu \mathrm{L}, 0.5$ mmol, 5 equiv) and DMAP (3 mg, $0.025 \mathrm{mmol}, 0.25$ equiv) in dry DMF for $2 \mathrm{~h}$. The progress of the ester-bond formation was listed on Table 1:

Table 1. Reaction progress during formation of ester bond using the following condition:Alloc-L-Ile-OH (107 mg, $0.5 \mathrm{mmol}, 5$ equiv), DIC (77 $\mu \mathrm{L}, 0.5 \mathrm{mmol}, 5$ equiv), pyridine (38 $\mu \mathrm{L}, 0.5 \mathrm{mmol}, 5$ equiv) and DMAP ( $3 \mathrm{mg}, 0.025 \mathrm{mmol}, 0.25$ equiv) in dry DMF for $2 \mathrm{~h}$

\begin{tabular}{|l|l|}
\hline Order of treatment & Conversion (\%) \\
\hline $1^{\text {st }}$ & 25 \\
\hline $2^{\text {nd }}$ & 38 \\
\hline $3^{\text {rd }}$ & 59 \\
\hline $4^{\text {th }}$ & 59 \\
\hline
\end{tabular}

Because there is no progress on ester-bond formation from the $3^{\text {rd }}$ treatment to the $4^{\text {th }}$ one, the reaction time was increased to $24 \mathrm{~h}$. However, traces of cleaved peptides, i.e. 6 and 7, were observed on the filtrate. Therefore, the firstly used method, i.e. Alloc-L-Ile$\mathrm{OH}$ (215 mg, $1 \mathrm{mmol}, 10$ equiv), DIC (77 $\mu \mathrm{L}, 0.5 \mathrm{mmol}, 5$ equiv) and DMAP (12 mg, $0.1 \mathrm{mmol}, 1$ equiv) in DCM/DMF (8:2), was used again but with decreasing the reaction time to $2 \mathrm{~h}$ only. Finally, $97 \%$ conversion was obtained. 


\section{HPLC chromatogram of Fmoc-L-Ile-L-Ser-D-Thr(Alloc-L-Ile)-L-Ala-OH 7:}

A linear gradient of $5-95 \% \mathrm{CH}_{3} \mathrm{CN} / \mathrm{H}_{2} \mathrm{O}$ and $0.1 \%$ TFA over 15 min was applied, with a flow rate of $1.0 \mathrm{~mL} / \mathrm{min}$ and detection at $220 \mathrm{~nm}$ using a Phenomenex $\mathrm{C}_{18}(3 \mu \mathrm{m}, 4.6 \times$ $50 \mathrm{~mm}$ ) column. $t_{R}($ pentadepsipeptide 7$)=10.74 \mathrm{~min}$

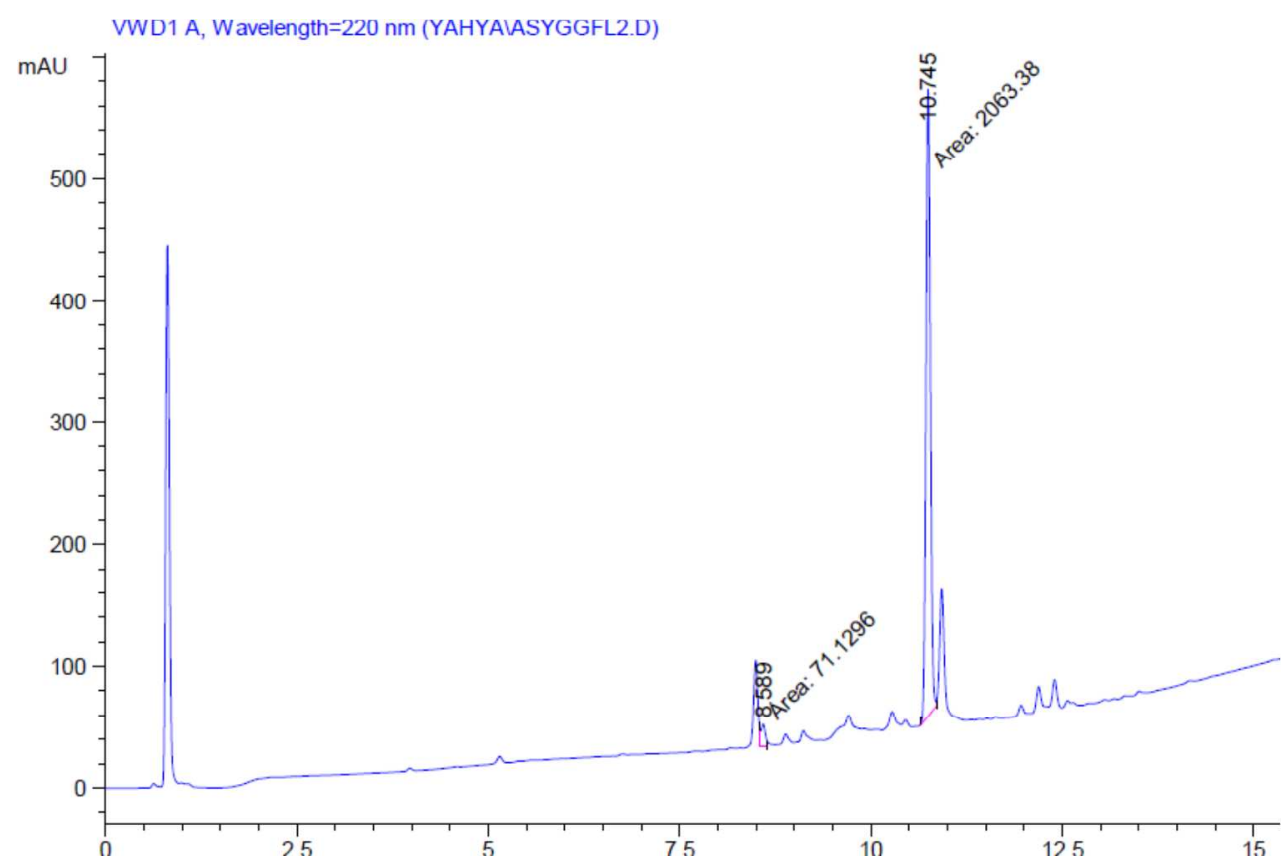

\section{MS}

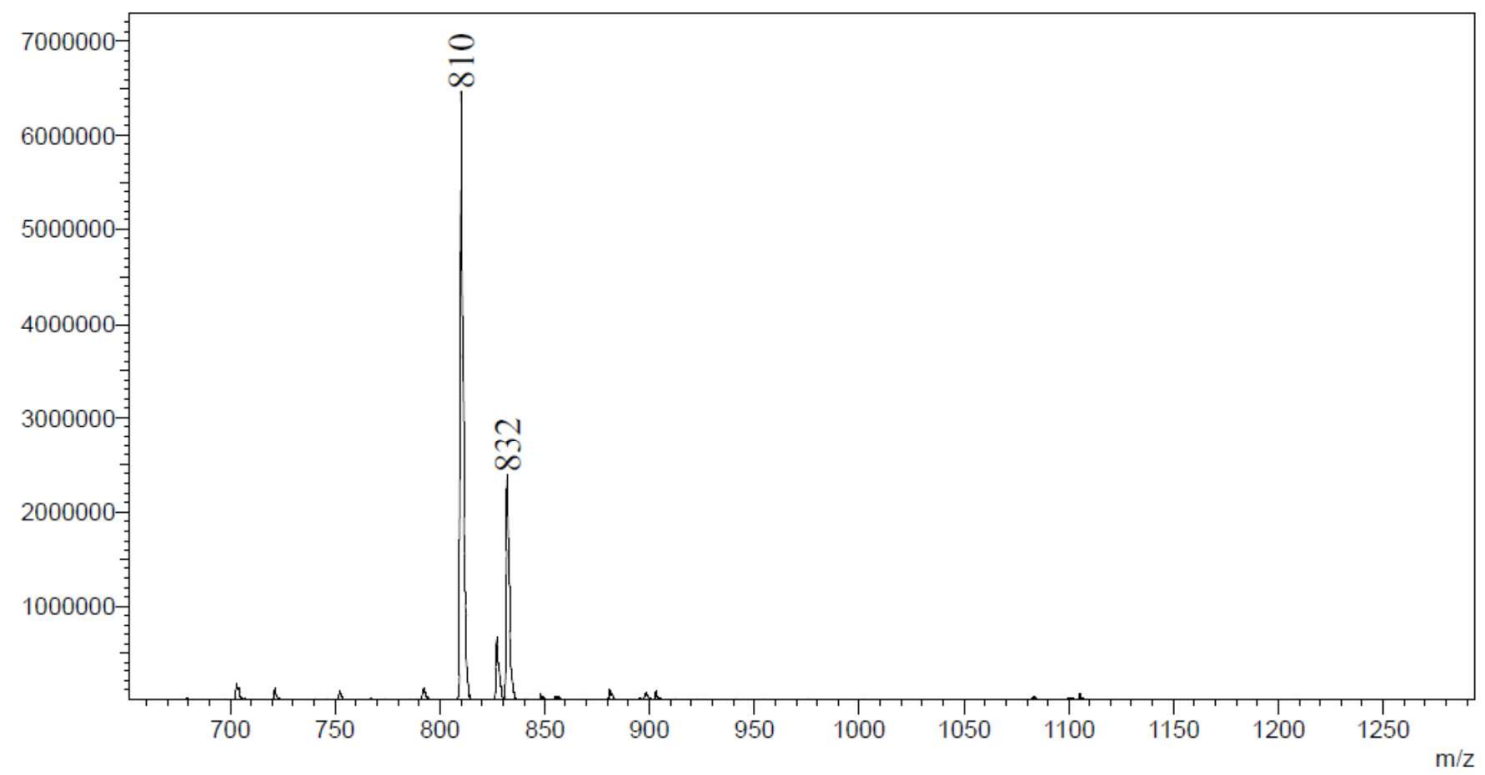




\section{c) Synthesis of protected precursor peptide 11:}

The resin was dried under vacuum and transferred onto microwave vial shielded from light by aluminum foil. Then, A solution of phenylsilane ( $124 \mu \mathrm{L}, 1 \mathrm{mmol}, 10$ equiv) and a catalytic amount of tetrakistriphenylphosphine palladium (0) $(11 \mathrm{mg}, 0.01 \mathrm{mmol}$, 0.1 equiv) in dry DCM $(1 \mathrm{~mL})$ was added.The reaction vessel was flushed with nitrogen and shacked for $15 \mathrm{~min}$. Mini-cleavage was performed in order to control the reaction

\section{HPLC chromatogram of Fmoc-L-Ile-L-Ser-D-Thr(H-L-Ile)-L-Ala-OH 8:}

A linear gradient of $5-95 \% \mathrm{CH}_{3} \mathrm{CN} / \mathrm{H}_{2} \mathrm{O}$ and $0.1 \%$ TFA over 15 min was applied, with a flow rate of $1.0 \mathrm{~mL} / \mathrm{min}$ and detection at $220 \mathrm{~nm}$ using a Phenomenex $\mathrm{C}_{18}(3 \mu \mathrm{m}, 4.6 \times$ $50 \mathrm{~mm}$ ) column. $t_{R}$ (pentadepsipeptide7) $=10.7 \mathrm{~min}$ (not observed) and $t_{R}($ pentadepsipeptide8 $)=8.37 \mathrm{~min}$

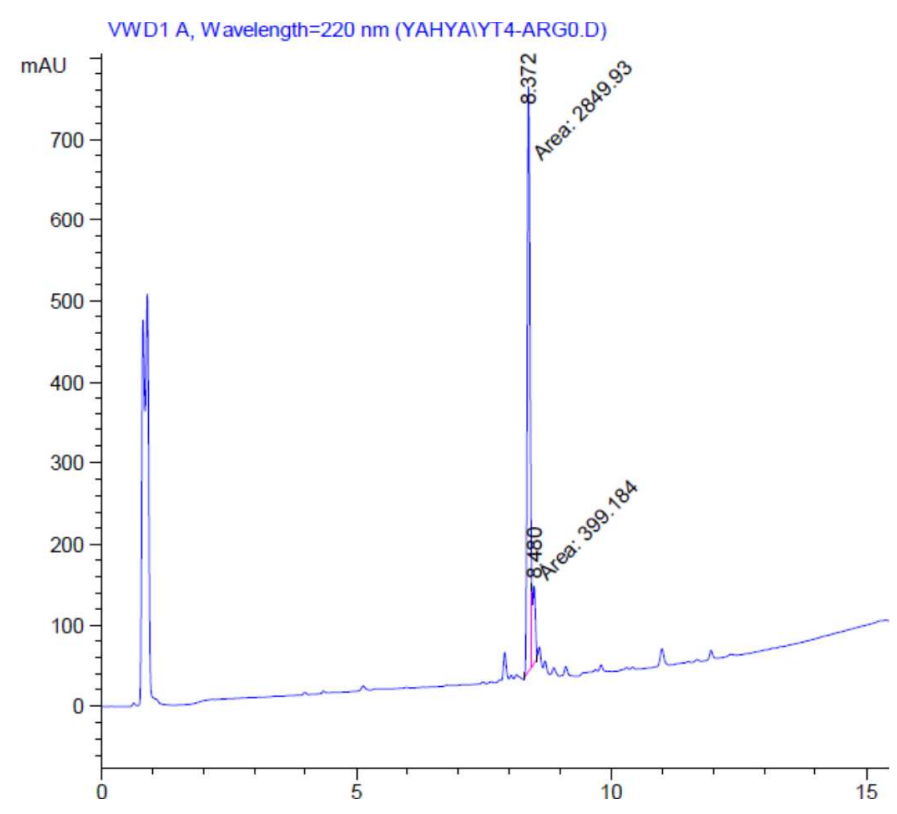

MS 


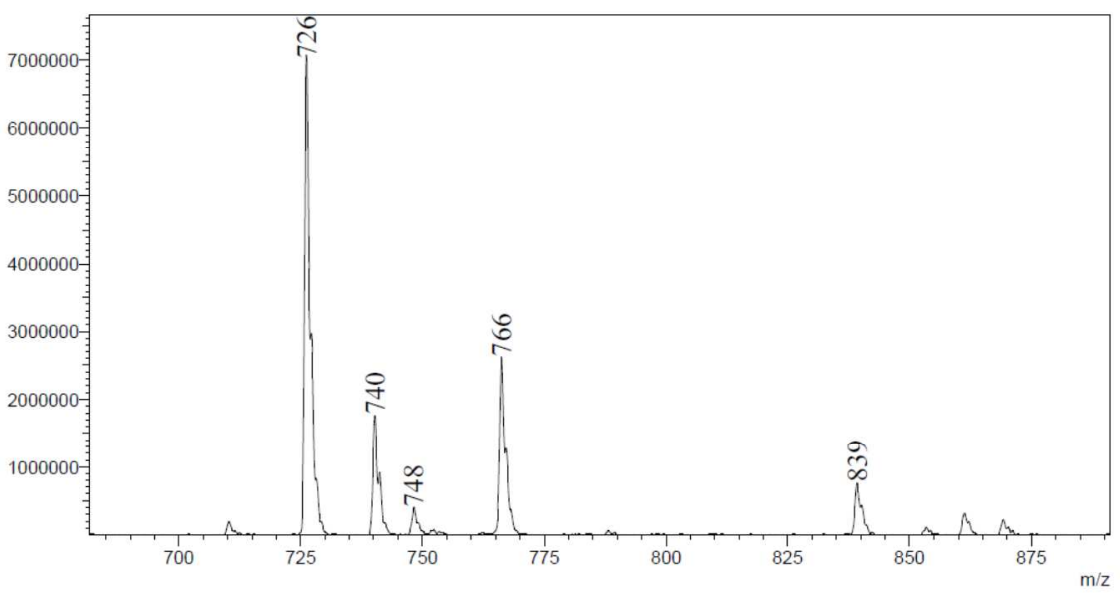

Then, Alloc-L-Arg(Pbf)-OH was added to the resin followed by removal of the Fmoc group and adding the following building blocks on the same order using the same protocol that mentioned above: Fmoc-D-allo-Ile-OH, Fmoc-D-Gln(Trt)-OH, Fmoc-L$\mathrm{Ser}\left({ }^{t} \mathrm{Bu}\right)-\mathrm{OH}, \mathrm{Fmoc}-\mathrm{L}-\mathrm{Ile}-\mathrm{OH}$ and Boc-D-NMe-Phe-OH.

Ninhydrin test was preformed after each cycle and it gave negative in all cases except Fmoc-D-Gln(Trt)-OH. So, it recoupled with using the following condtion: Fmoc-AA$\mathrm{OH} / \mathrm{DIC} / \mathrm{K}$-Oxyma (3:3:3) in $1 \mathrm{~mL} \mathrm{DMF}$ for $1 \mathrm{~h}$.

HPLC chromatogram of 11-mer depsipeptide 10:

A linear gradient of $5-95 \% \mathrm{CH}_{3} \mathrm{CN} / \mathrm{H}_{2} \mathrm{O}$ and $0.1 \%$ TFA over 15 min was applied, with a flow rate of $1.0 \mathrm{~mL} / \mathrm{min}$ and detection at $220 \mathrm{~nm}$ using a Phenomenex $\mathrm{C}_{18}(3 \mu \mathrm{m}, 4.6 \times$ $50 \mathrm{~mm}$ ) column. $t_{R}(11$-mer depsipeptide 10$)=7.17 \mathrm{~min}$, purity $=68.6 \%$

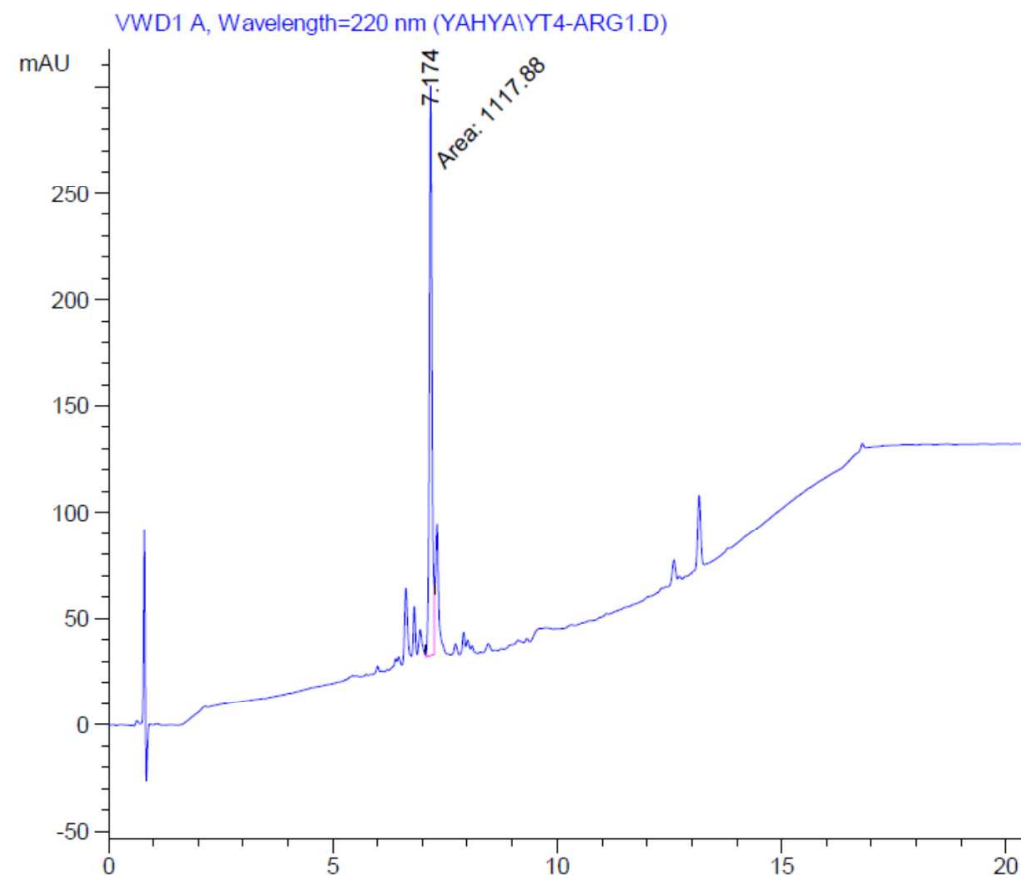


MALDI-TOF of 11-mer depsipeptide 10:

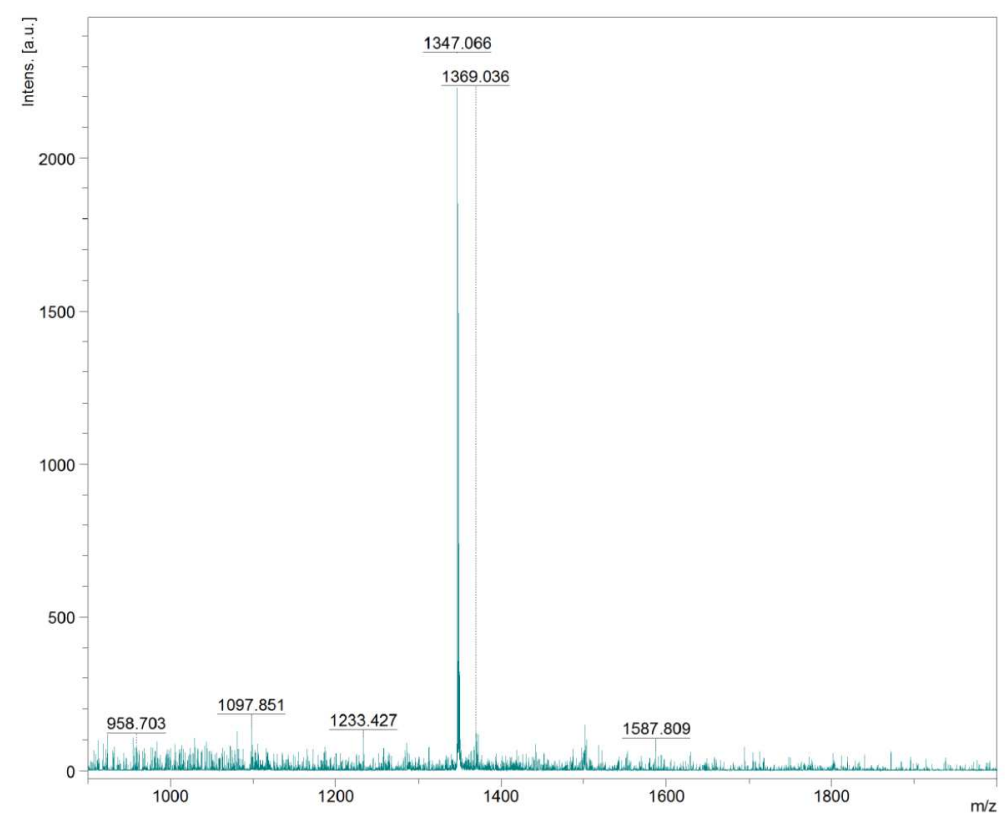

Removal of the Alloc group was performed as the procedure written above HPLC chromatogram of 11-mer depsipeptide11:

A linear gradient of $5-95 \% \mathrm{CH}_{3} \mathrm{CN} / \mathrm{H}_{2} \mathrm{O}$ and $0.1 \%$ TFA over 15 min was applied, with a flow rate of $1.0 \mathrm{~mL} / \mathrm{min}$ and detection at $220 \mathrm{~nm}$ using a Phenomenex $\mathrm{C}_{18}(3 \mu \mathrm{m}, 4.6 \times$ $50 \mathrm{~mm})$ column. $t_{R}\left(11\right.$-mer depsipeptide10) $=7.17 \mathrm{~min}$ (not observed), $t_{R}(11$-mer depsipeptide11) $=6.41 \mathrm{~min}$ 


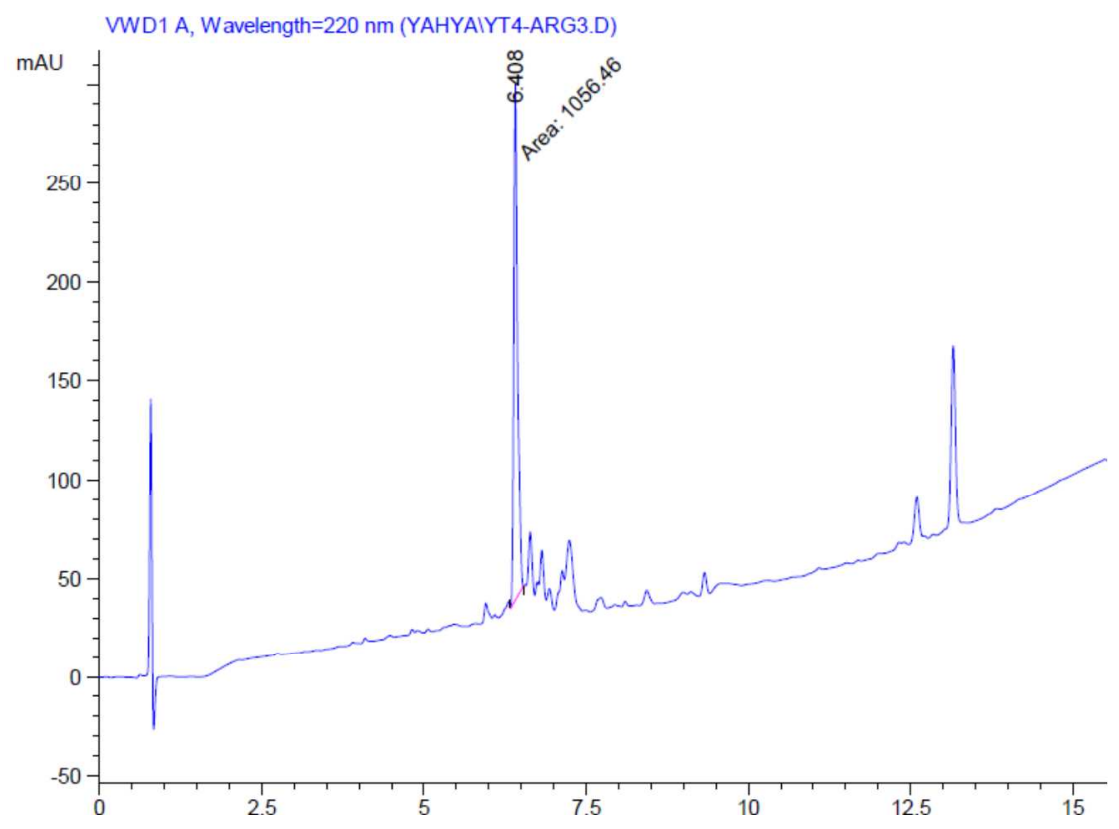

MALDI-TOF of 11-mer depsipeptide11:

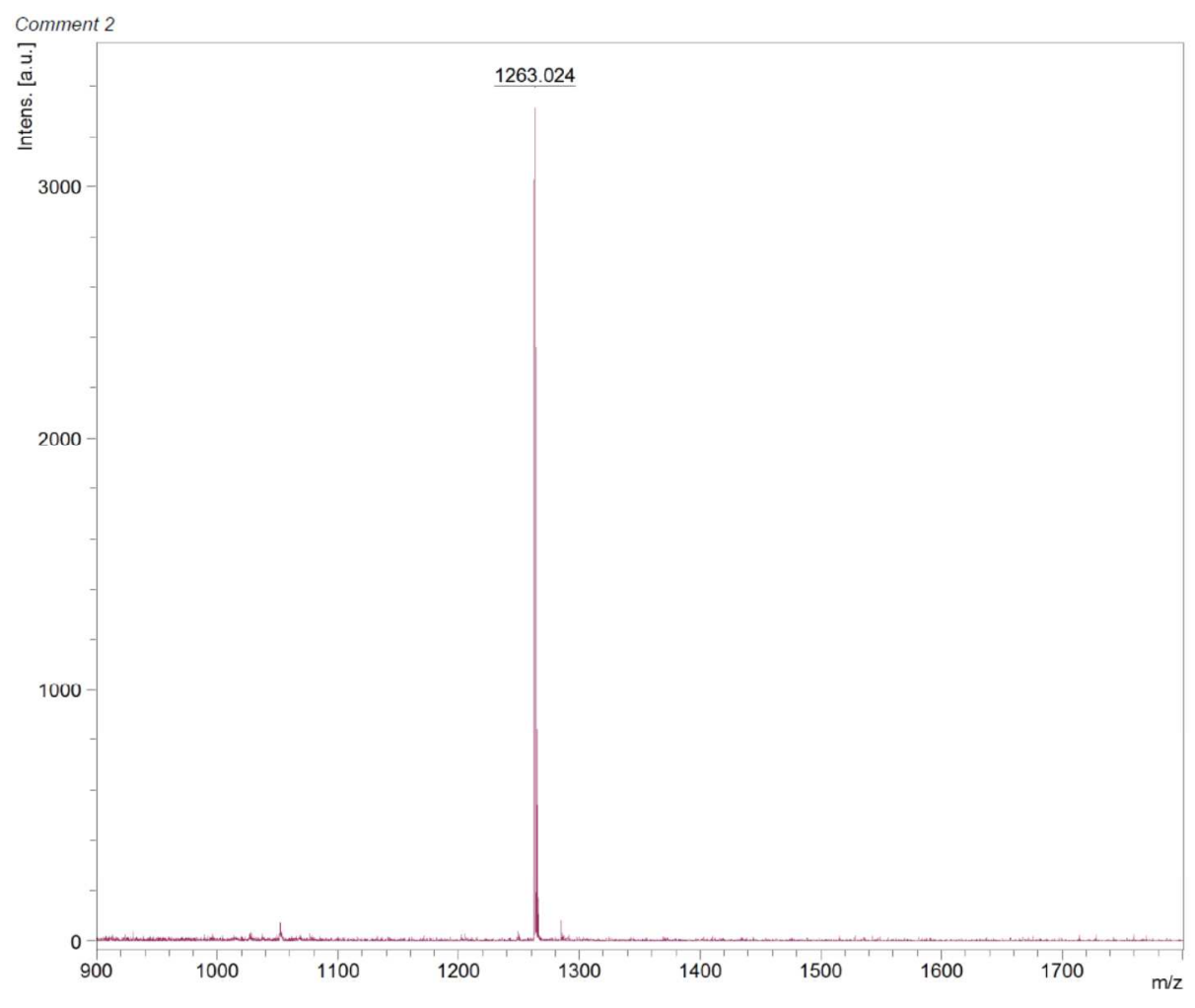

The resin was dried under vacuum and treatment with $1 \%$ TFA in DCM $(5 \times 30 \mathrm{~s})$ and collected on water. Then, TFA and DCM were evaporated and MeCN was added to dissolve the precipitated peptide, and then lyophilized to get $\mathbf{1 2}$ as a white solid $(75 \mathrm{mg}$, $38 \%$ yield). 


\section{d) Cyclization and removal of all protecting groups:}

In $500 \mathrm{~mL}$ round flask, DIEA ( $40 \mu \mathrm{L}, 0.23 \mathrm{mmol}, 6$ equiv), OxymaPure (16 mg, 0.11 mmol, 3 equiv) and $370 \mathrm{~mL}$ DCM were added to 11 -mer depsipeptide12(75 $\mathrm{mg}, 0.038$ $\mathrm{mmol}$ ) in $5 \mathrm{~mL}$ DMF. Then, it cooled to $0{ }^{\circ} \mathrm{C}$ by ice bath followed by adding PyAOP (57 $\mathrm{mg}, 0.11 \mathrm{mmol}$, 3equiv) in $5 \mathrm{~mL}$ to the reaction mixture. The reaction was stirred $1 \mathrm{~d}$ and monitored by HPLC.

HPLC of 11-mer depsipeptide12 prior to cyclization reaction in DMF:

A linear gradient of $0-100 \% \mathrm{CH}_{3} \mathrm{CN} / \mathrm{H}_{2} \mathrm{O}$ and $0.1 \%$ TFA over 15 min was applied, with a flow rate of $1.0 \mathrm{~mL} / \mathrm{min}$ and detection at $220 \mathrm{~nm}$ using a Phenomenex $\mathrm{C}_{18}(3 \mu \mathrm{m}, 4.6 \times$ $50 \mathrm{~mm})$ column. $t_{R}(11-\mathrm{mer}$ depsipeptide12) $=13.76 \mathrm{~min}$

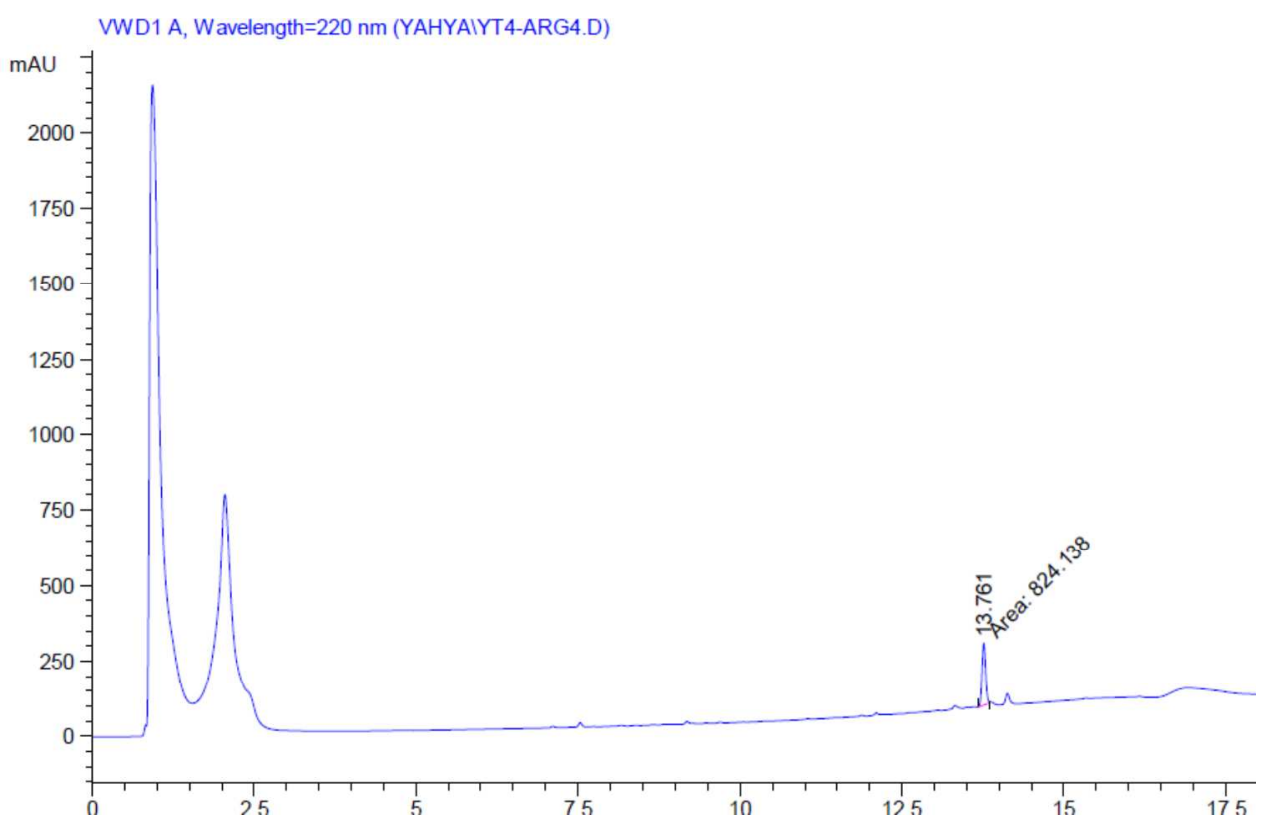

MALDI-TOF of 11-mer depsipeptide12 prior to cyclization reaction in DMF: 


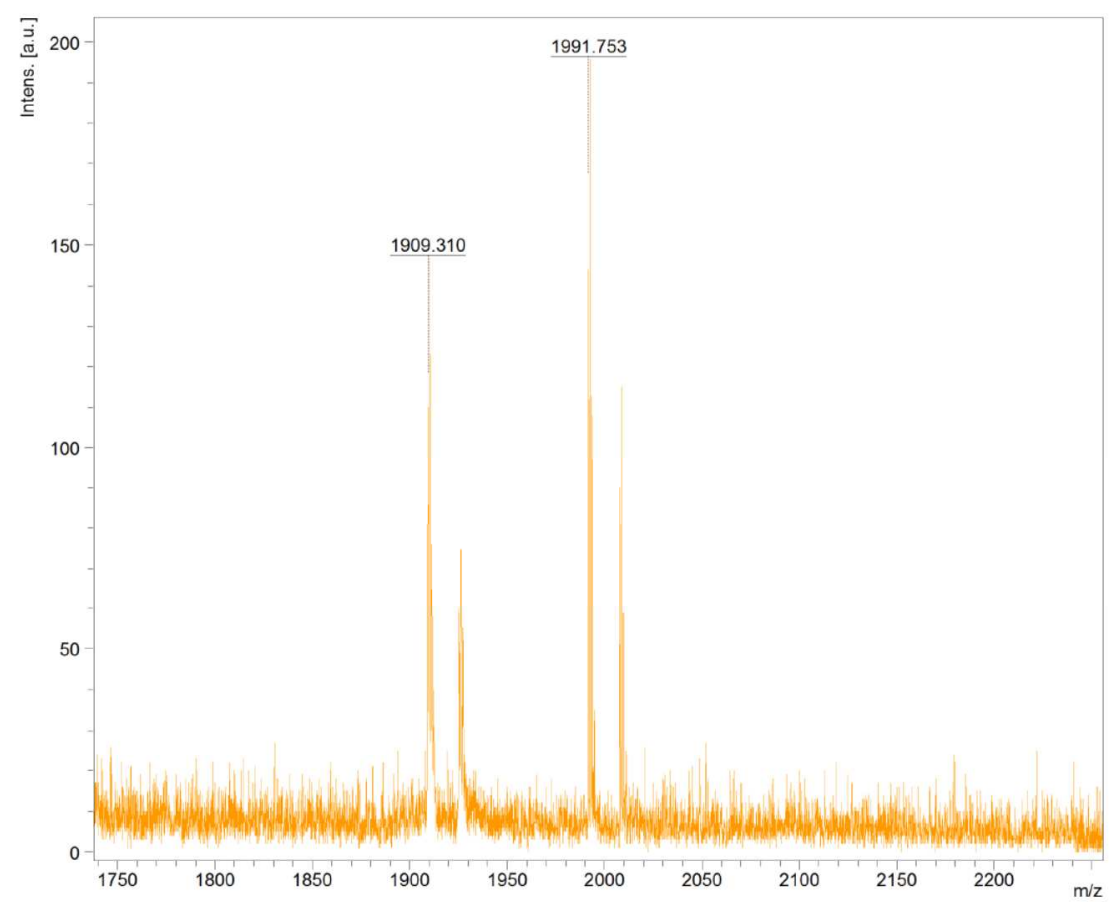

HPLC of cyclization reaction in one day:

A linear gradient of $0-100 \% \mathrm{CH}_{3} \mathrm{CN} / \mathrm{H}_{2} \mathrm{O}$ and $0.1 \%$ TFA over 15 min was applied, with a flow rate of $1.0 \mathrm{~mL} / \mathrm{min}$ and detection at $220 \mathrm{~nm}$ using a Phenomenex $\mathrm{C}_{18}(3 \mu \mathrm{m}, 4.6 \times$ $50 \mathrm{~mm}$ ) column. $t_{R}\left(11-\mathrm{mer}\right.$ depsipeptide12) $=13.76 \mathrm{~min}$ (not observed), $t_{R}($ cyclic protected peptide) $=15.60 \mathrm{~min}$

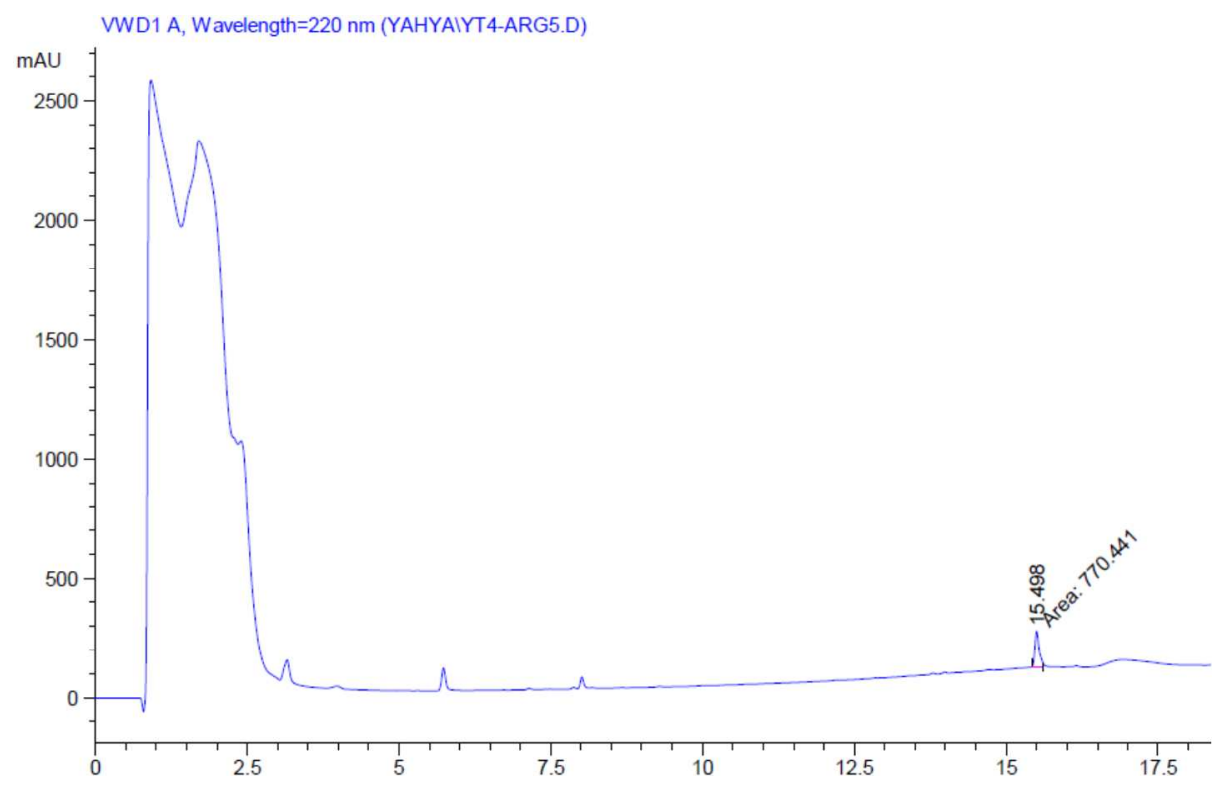

MALDI-TOF of cyclization reaction in one day: 


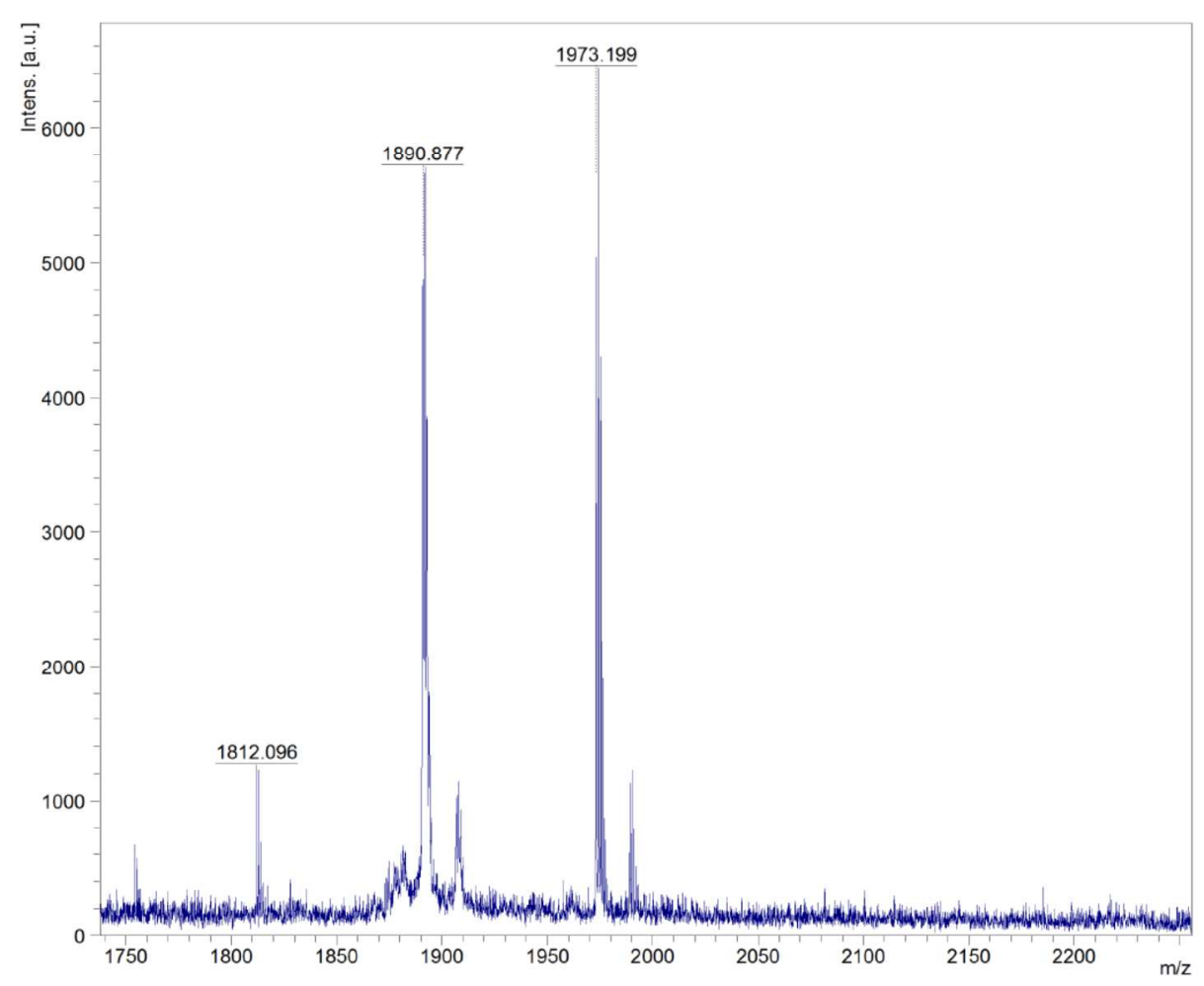

Then, DCM was removed by rotary evaporator while DMF was removed under nitrogen. $10 \mathrm{~mL}$ of the TFA/TIS/ $\mathrm{H}_{2} \mathrm{O}(95: 2.5: 2.5)$ was added and stirred for $2 \mathrm{~h}$. The solvent and residues from the cleavage cocktailwere concentrated under nitrogen. The crude peptide wasprecipitated with cold $\mathrm{Et}_{2} \mathrm{O}(3 \times 10 \mathrm{~mL})$. The crude peptide was confirmed by HPLC and MALDI-TOF.

HPLC chromatogram of crude L-Arg analogue of teixobactin $\mathbf{1}$ :

A linear gradient of $25-40 \% \mathrm{CH}_{3} \mathrm{CN} / \mathrm{H}_{2} \mathrm{O}$ and $0.1 \%$ TFA over 15 min was applied, with a flow rate of $1.0 \mathrm{~mL} / \mathrm{min}$ and detection at $220 \mathrm{~nm}$ using a Phenomenex $\mathrm{C}_{18}(3 \mu \mathrm{m}, 4.6 \times$ $50 \mathrm{~mm})$ column. $t_{R}(\mathrm{~L}-\mathrm{Arg}$ analogue of teixobactin $\mathbf{1})=8.03 \mathrm{~min}$, purity $=82.5 \%$ 


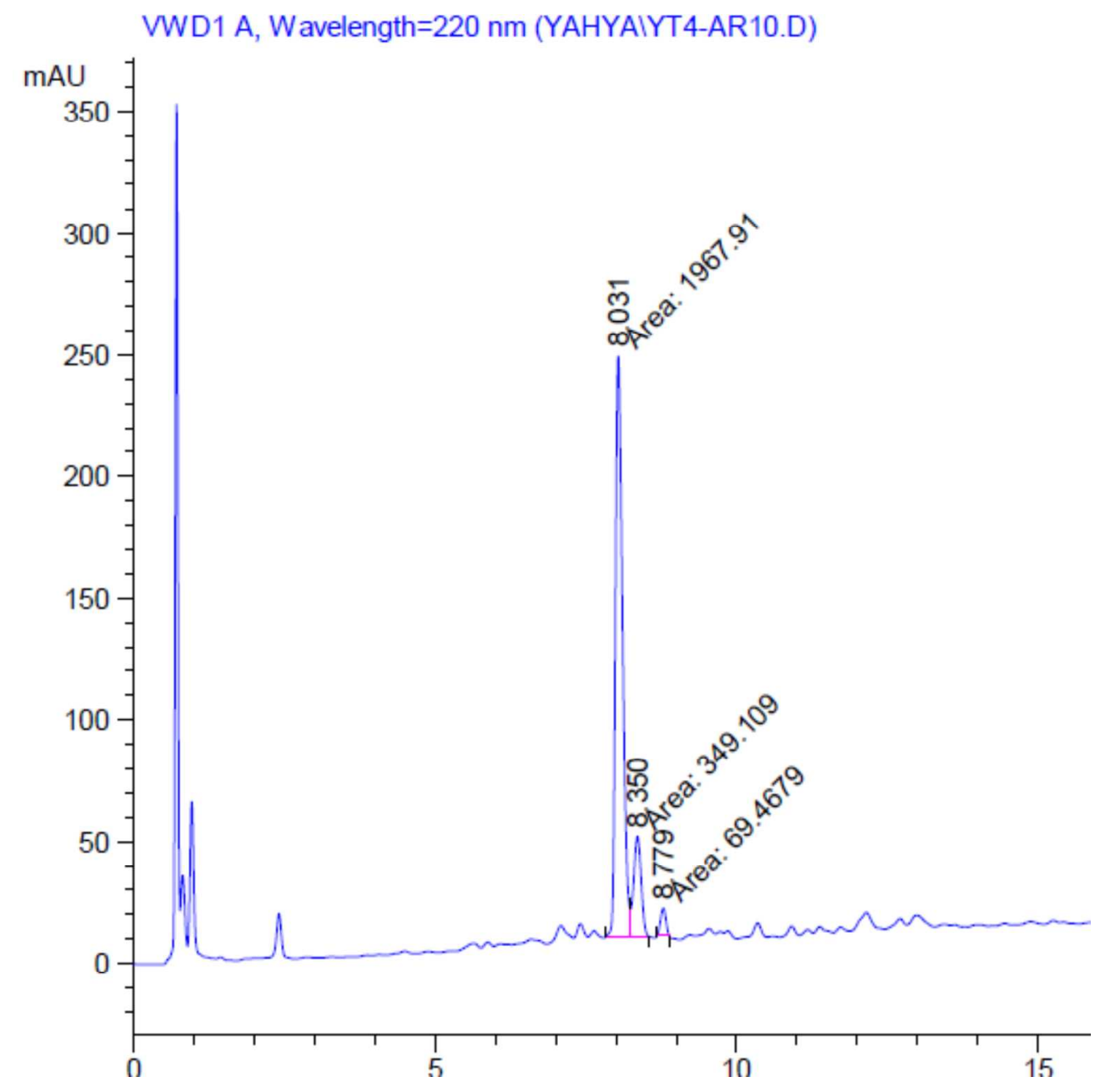

MALDI-TOF of crude L-Arg analogue of teixobactin 1: 


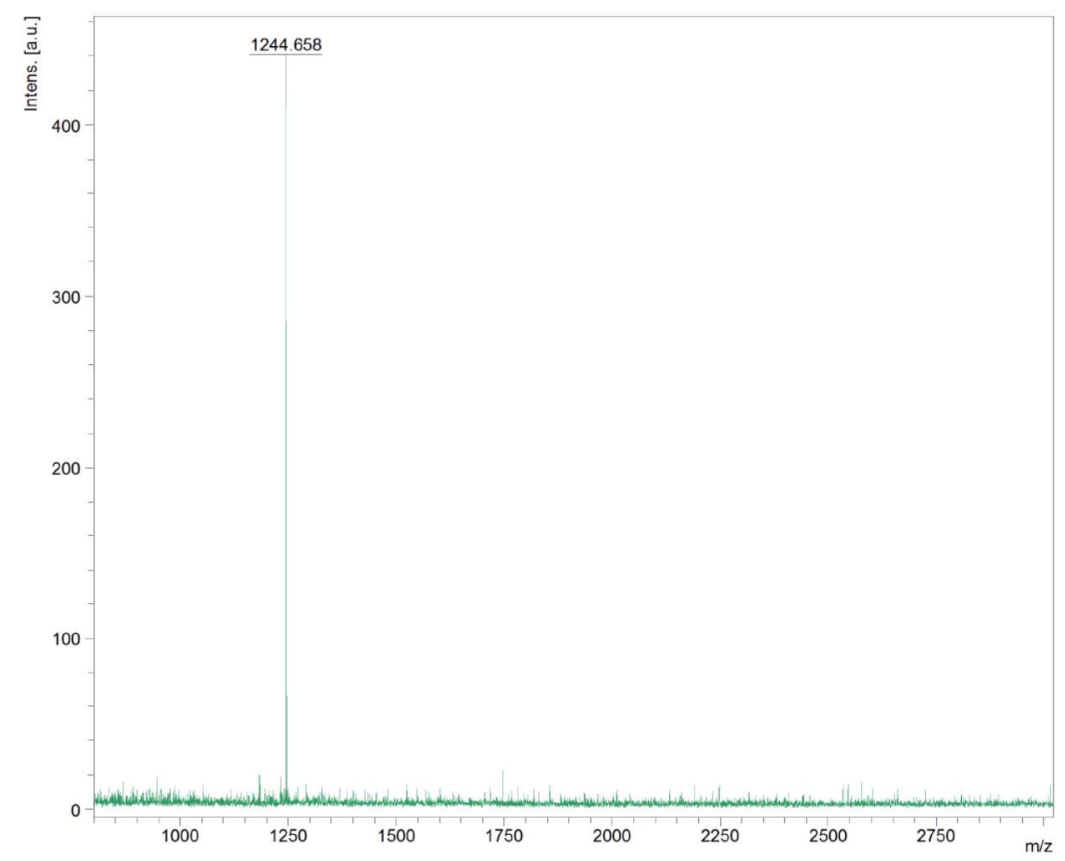

The crude peptide was purified by prep-HPLC

\section{Condition:}

A linear gradient of $25-60 \% \mathrm{CH}_{3} \mathrm{CN} / \mathrm{H}_{2} \mathrm{O}$ and $0.1 \%$ TFA over 30 min was applied, with a flow rate of $15.0 \mathrm{~mL} / \mathrm{min}$ and detection at $220 \mathrm{~nm}$ using a PhenomenexLumaC $\mathrm{C}_{18}(2)$ column $(10 \mu \mathrm{m}, 21.1 \times 250 \mathrm{~mm}), t_{R}(\mathrm{~L}-\mathrm{Arg}$ analogue of teixobactin1 $)=24.2 \mathrm{~min}$

The final product of $\mathbf{1}$ was obtained after lyophilizing as a white solid $(7.7 \mathrm{mg}, 6 \%$ yield).

HPLC of the pure final product: 
A linear gradient of $25-40 \% \mathrm{CH}_{3} \mathrm{CN} / \mathrm{H}_{2} \mathrm{O}$ and $0.1 \%$ TFA over 15 min was applied, with a flow rate of $1.0 \mathrm{~mL} / \mathrm{min}$ and detection at $220 \mathrm{~nm}$ using a Phenomenex $\mathrm{C}_{18}(3 \mu \mathrm{m}, 4.6 \times$ $50 \mathrm{~mm})$ column, $t_{R}(\mathrm{~L}-\mathrm{Arg}$ analogue of teixobactin $\mathbf{1})=8.25 \mathrm{~min}$

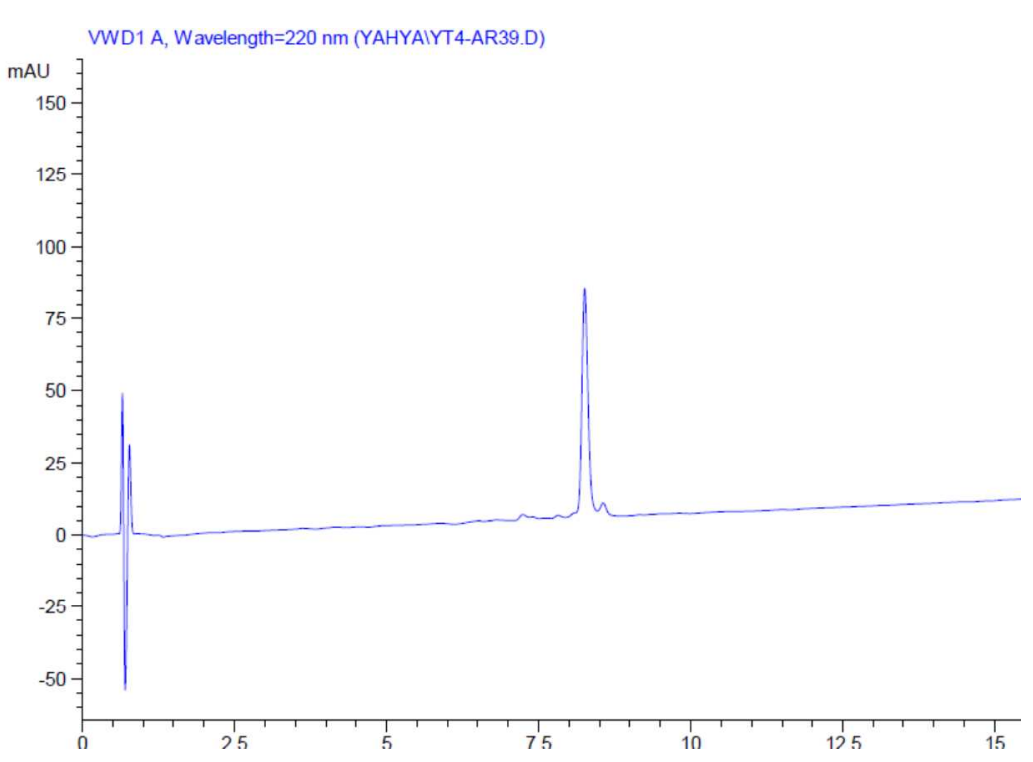

HRMS 


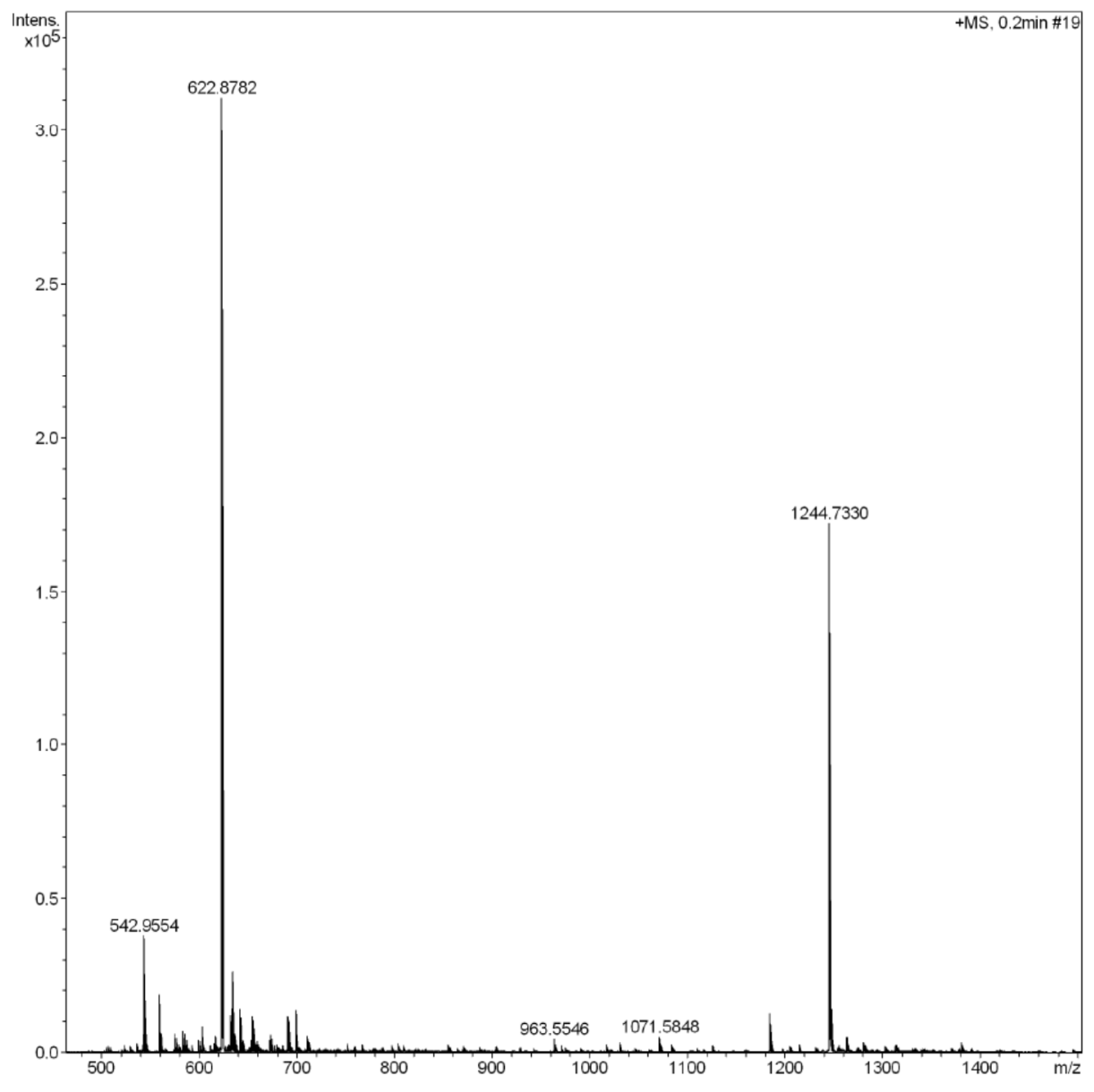

Expected exact mass of $\mathbf{1}\left(\mathrm{C}_{58} \mathrm{H}_{97} \mathrm{~N}_{10} \mathrm{O}_{15}\right)[\mathrm{M}+\mathrm{H}]^{+}: 1244.7361 \mathrm{Da}$

Observed exact mass of $\mathbf{1}[\mathrm{M}+\mathrm{H}]^{+}: 1244.7330 \mathrm{Da}$

Error $=3.3 \mathrm{ppm}$ 
Table 2. NMR assignment of $\mathbf{1}$ in DMSO- $d_{6}$

\begin{tabular}{|c|c|c|c|c|c|}
\hline Position & Carbon & Proton & Position & Carbon & Proton \\
\hline 1 & 31.9 & $2.48(3 \mathrm{H}, \mathrm{s})$ & 29 & 56.4 & $4.39(1 \mathrm{H}, \mathrm{m})$ \\
\hline 2 & 61.8 & $4.17(1 \mathrm{H}, \mathrm{m})$, & $29-\mathrm{NH}$ & - & $7.77(1 \mathrm{H}, \mathrm{d}, 8.88 \mathrm{~Hz})$ \\
\hline 2-NH & - & $\begin{array}{l}9.06(2 \mathrm{H}, \mathrm{s})^{\mathrm{a}} \\
\text { COSY with } 1-\mathrm{CH}_{3}\end{array}$ & 30 & 36.6 & $1.82(1 \mathrm{H}, \mathrm{m})^{\mathrm{e}}$ \\
\hline 3 & 36.5 & $\begin{array}{l}3.00(1 \mathrm{H}, \mathrm{dd}, 13.26, \\
9.66 \mathrm{~Hz}) \\
3.14(1 \mathrm{H}, \mathrm{dd}, 13.5, \\
5.76 \mathrm{~Hz}) .\end{array}$ & 31 & 15.5 & $0.88(3 \mathrm{H}, \mathrm{m})$ \\
\hline 4 & 135.0 & - & 32 & 25.3 & $\begin{array}{l}1.44(1 \mathrm{H}, \mathrm{m})^{\mathrm{d}} \\
1.55(1 \mathrm{H}, \mathrm{m})\end{array}$ \\
\hline 5,5 & 129.7 & $7.24(2 \mathrm{H}, \mathrm{d}, 7.5 \mathrm{~Hz})$ & 33 & 11.3 & $0.82(3 \mathrm{H}, \mathrm{m})$ \\
\hline $6,6^{\prime}$ & 129.0 & $7.33(2 \mathrm{H}, \mathrm{t}, 7.38 \mathrm{~Hz})$ & 34 & 171.6 & - \\
\hline 7 & 127.6 & $7.27(1 \mathrm{H}, \mathrm{t}, 7.38 \mathrm{~Hz})$ & 35 & 52.6 & $4.35(1 \mathrm{H}, \mathrm{m})^{\mathrm{b}, \mathrm{g}}$ \\
\hline 8 & 167.0 & - & $35-\mathrm{NH}$ & - & $8.03(1 \mathrm{H}, \mathrm{m})^{\mathrm{f}}$ \\
\hline 9 & 57.8 & $4.16(1 \mathrm{H}, \mathrm{t}, 7.62 \mathrm{~Hz})$ & 36 & 62.4 & $\begin{array}{l}3.62(1 \mathrm{H}, \mathrm{m}) \\
3.84(1 \mathrm{H}, \mathrm{m}\end{array}$ \\
\hline 9-NH & - & $8.49(1 \mathrm{H}, \mathrm{d}, 9.54 \mathrm{~Hz})$ & $36-\mathrm{OH}$ & & \\
\hline 10 & 36.6 & $1.55(1 \mathrm{H}, \mathrm{m})$ & 37 & $169.5^{\mathrm{g}}$ & - \\
\hline 11 & 15.5 & $0.62(3 \mathrm{H}, \mathrm{d}, 6.7 \mathrm{~Hz})$ & 38 & 56.4 & $4.5(1 \mathrm{H}, \mathrm{m})$ \\
\hline 12 & 24.3 & $\begin{array}{l}0.74(1 \mathrm{H}, \mathrm{m}) \\
1.05(1 \mathrm{H}, \mathrm{m})\end{array}$ & $38-\mathrm{NH}$ & & $8.76(1 \mathrm{H}, \mathrm{m})^{\mathrm{h}}$ \\
\hline 13 & 11.3 & $0.66(3 \mathrm{H}, \mathrm{t}, 7.4 \mathrm{~Hz})$ & 39 & 71.0 & $5.38(1 \mathrm{H}, \mathrm{m})$ \\
\hline 14 & 170.6 & - & 40 & 15.8 & $1.11(3 \mathrm{H}, \mathrm{d}, 6.3 \mathrm{~Hz})$ \\
\hline 15 & 55.5 & $4.35(1 \mathrm{H}, \mathrm{m})^{\mathrm{b}}$ & 41 & $158.4^{\mathrm{g}}$ & - \\
\hline $15-\mathrm{NH}$ & - & $7.92(1 \mathrm{H}, \mathrm{m})^{\mathrm{f}}$ & 42 & 52.1 & $\begin{array}{l}3.93(1 \mathrm{H}, \text { quintet, } \\
7.14 \mathrm{~Hz})\end{array}$ \\
\hline 16 & 62.4 & $\begin{array}{l}3.55(1 \mathrm{H}, \mathrm{m}) \\
3.62(1 \mathrm{H}, \mathrm{m})^{\mathrm{c}}\end{array}$ & $42-\mathrm{NH}$ & & $8.13(1 \mathrm{H}, \mathrm{m})$ \\
\hline $16-\mathrm{OH}$ & - & & 43 & 17.3 & $1.31(3 \mathrm{H}, \mathrm{d}, 7.26 \mathrm{~Hz})$ \\
\hline 17 & 170.1 & - & 44 & 172.8 & - \\
\hline 18 & $57.2^{\mathrm{g}}$ & $4.35(1 \mathrm{H}, \mathrm{m})^{\mathrm{b}}$ & 45 & 52.1 & $3.6(1 \mathrm{H}, \mathrm{m})$ \\
\hline $18-\mathrm{NH}$ & - & $8.03(1 \mathrm{H}, \mathrm{m})^{\mathrm{f}}$ & $45-\mathrm{NH}$ & - & \\
\hline 19 & 28.6 & $\begin{array}{l}1.72(1 \mathrm{H}, \mathrm{m}) \\
1.88(1 \mathrm{H}, \mathrm{m})\end{array}$ & 46 & 25.7 & $1.44(2 \mathrm{H}, \mathrm{m})^{\mathrm{d}}$ \\
\hline 20 & 31.9 & $2.1(2 \mathrm{H}, \mathrm{m})$ & 47 & 29.4 & $1.26(2 \mathrm{H}, \mathrm{m})$ \\
\hline 21 & 174.4 & - & 48 & 43.9 & $3.17(2 \mathrm{H}, \mathrm{s})$ \\
\hline 21-NH 2 & - & $\begin{array}{l}6.76(1 \mathrm{H}, \mathrm{s}) \\
7.21(1 \mathrm{H}, \mathrm{s})\end{array}$ & $48-\mathrm{NH}$ & - & \\
\hline 22 & 171.3 & - & 49 & 157.2 & - \\
\hline 23 & $54.1^{\mathrm{g}}$ & $4.29(1 \mathrm{H}, \mathrm{m})$ & 49-NH & - & \\
\hline $23-\mathrm{NH}$ & - & $8.23(1 \mathrm{H}, \mathrm{m})$ & $49-\mathrm{NH} 2$ & - & \\
\hline
\end{tabular}




\begin{tabular}{|l|l|l|l|l|l|}
\hline 24 & 37.5 & $1.82(1 \mathrm{H}, \mathrm{m})^{\mathrm{e}}$ & 50 & 171.9 & - \\
\hline 25 & 14.7 & $0.82(3 \mathrm{H}, \mathrm{m})$ & 51 & 57.5 & $4.05(1 \mathrm{H}, \mathrm{t}, 9.7 \mathrm{~Hz})$ \\
\hline 26 & 26.2 & $1.11(1 \mathrm{H}, \mathrm{m})$ & $51-\mathrm{NH}$ & - & $8.18(1 \mathrm{H}, \mathrm{m})$ \\
& & $1.31(1 \mathrm{H}, \mathrm{m})$ & & & \\
\hline 27 & 10.5 & $0.82(3 \mathrm{H}, \mathrm{m})$ & 52 & 37.0 & $1.82\left(1 \mathrm{H}, \mathrm{m}^{\mathrm{e}}\right.$ \\
\hline 28 & 171.6 & - & 53 & 16.0 & $0.82(3 \mathrm{H}, \mathrm{m})$ \\
\hline & & & 54 & 24.7 & $1.16(1 \mathrm{H}, \mathrm{m})$ \\
& & & & & $1.44(1 \mathrm{H}, \mathrm{m})^{\mathrm{d}}$ \\
\hline & & & 55 & 11.9 & $0.82(3 \mathrm{H}, \mathrm{m})$ \\
\hline & & & 56 & 168.7 & - \\
\hline
\end{tabular}

${ }^{a}$ Appears with two protons due to ammonium salt.

b,d,e,f Assignments may be switched due to overlap.

${ }^{\mathrm{c}}$ Water residual peak overlap.

g Differed by greater than $1.0 \mathrm{ppm}$ shift as compared to the natural product ${ }^{2}$ elucidation, however was unambiguously assigned using 2D correlations.

${ }^{\mathrm{h}}$ Was not assigned on natural product ${ }^{2}$ elucidation but now allocated.

Note: There are 5 protons unassigned from the integration of the ${ }^{1} \mathrm{H}$ NMR spectrum $(3.1(2 \mathrm{H}), 4.6,4.9$, and $7.6 \mathrm{ppm}$ ) these signals were attributed to the NH's on the guanidine moiety, which appears as its ammonium salt similar to the natural product ${ }^{2}$ elucidation.

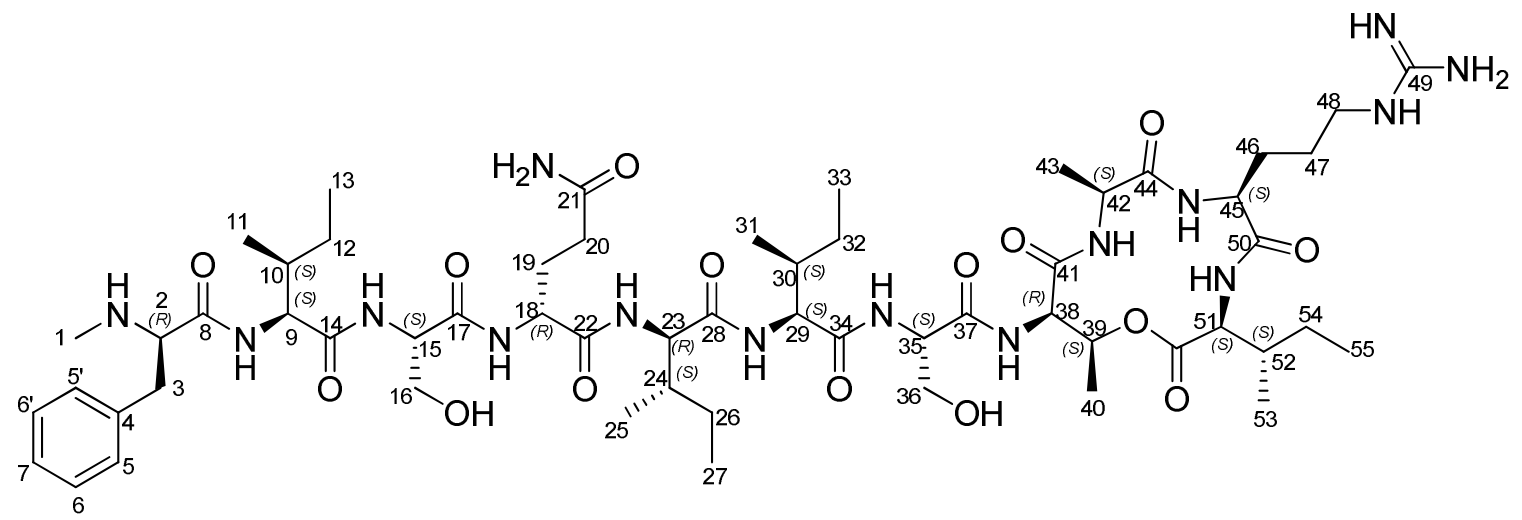

Structure with numbering of $\mathbf{1}$ with the NMR assignments appearing in Table 2. 


\section{NMR spectra:}
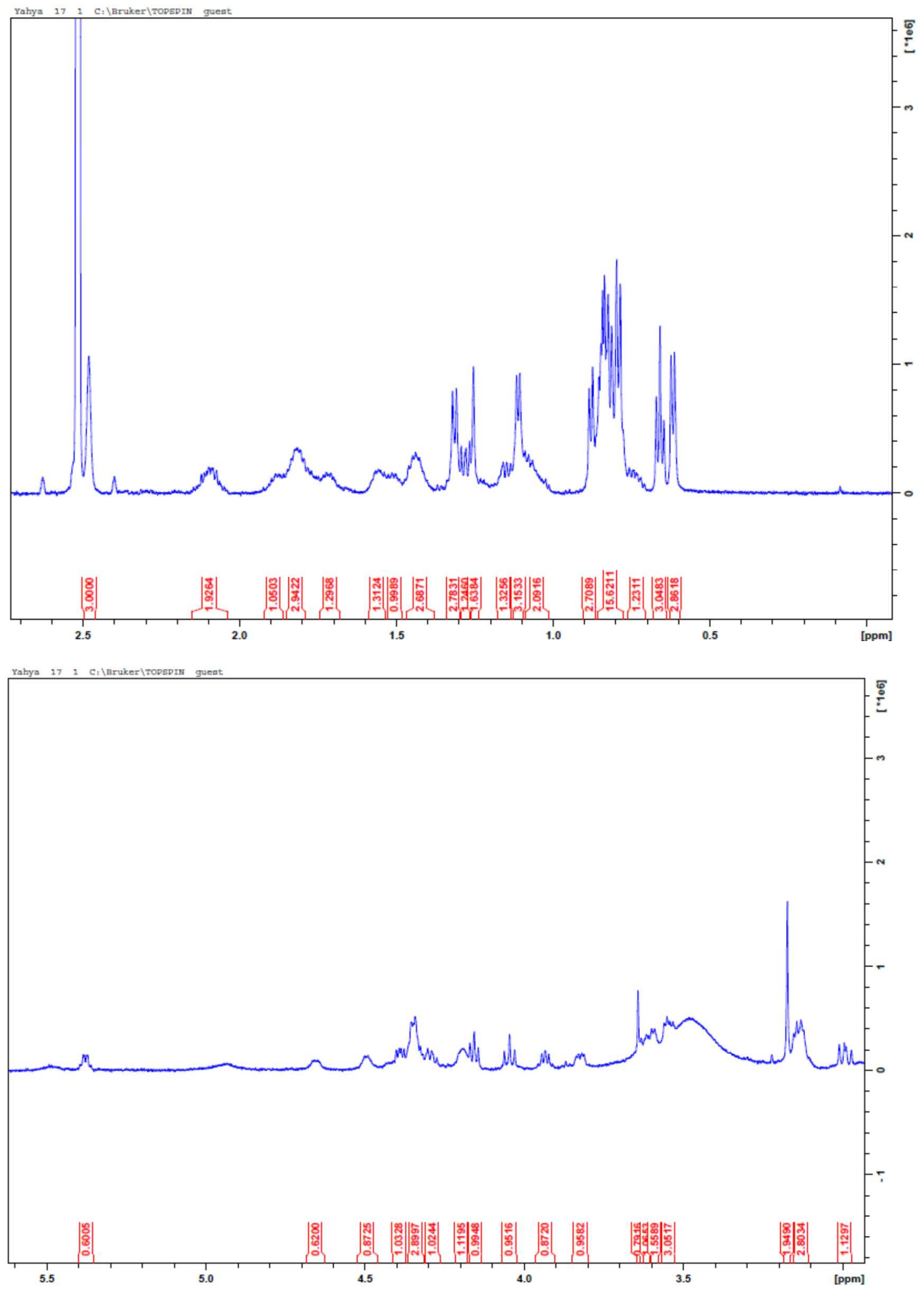

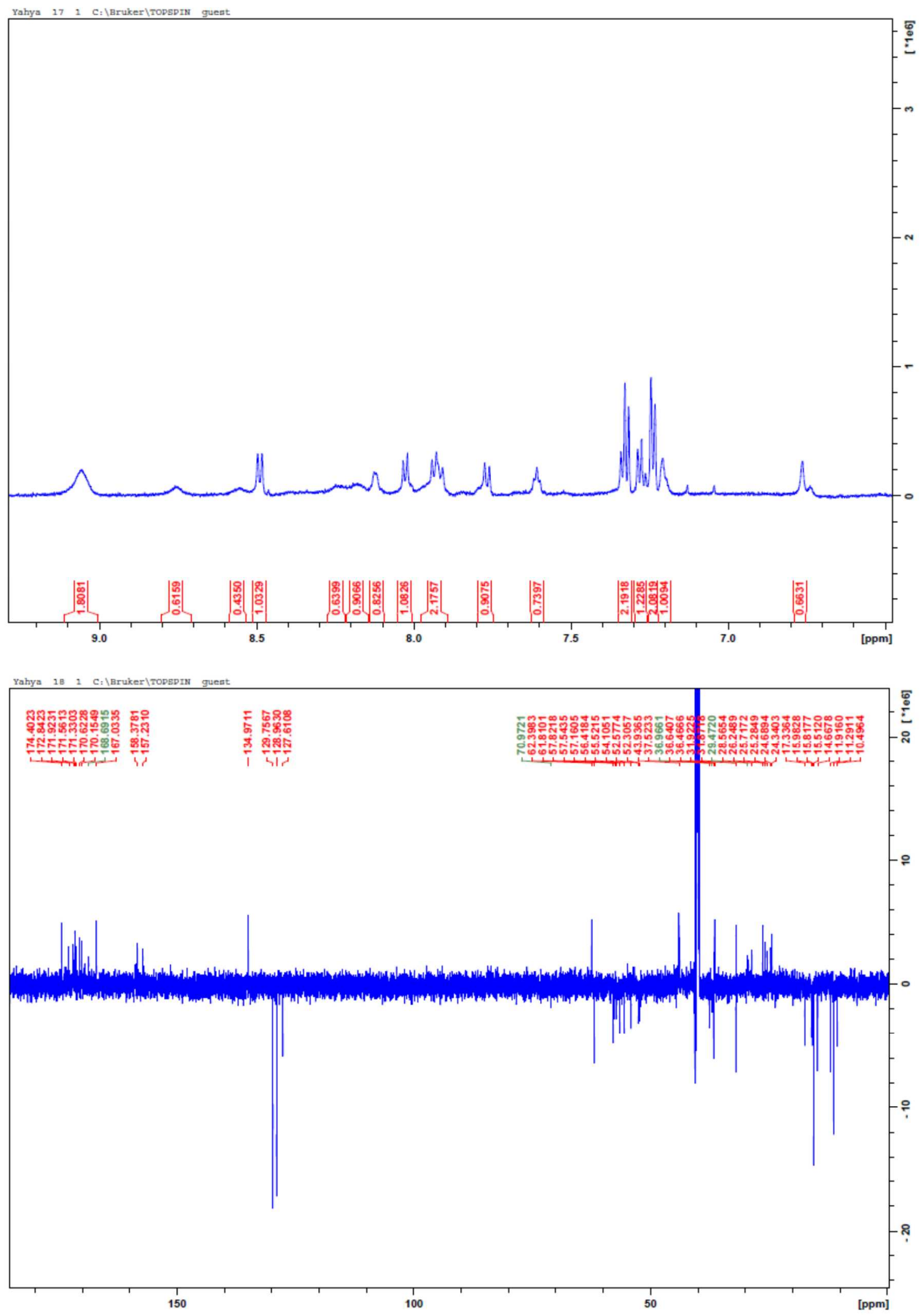

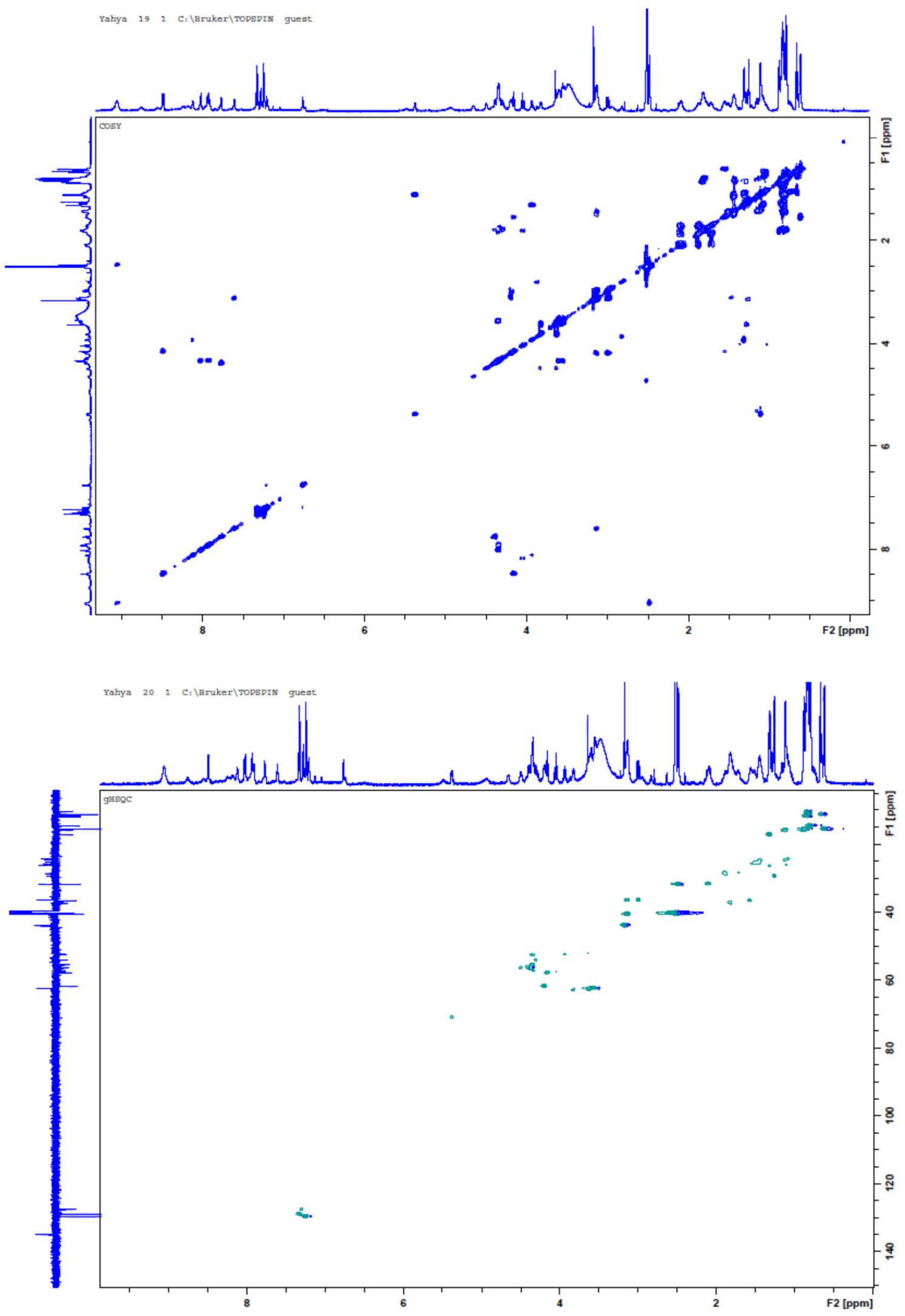


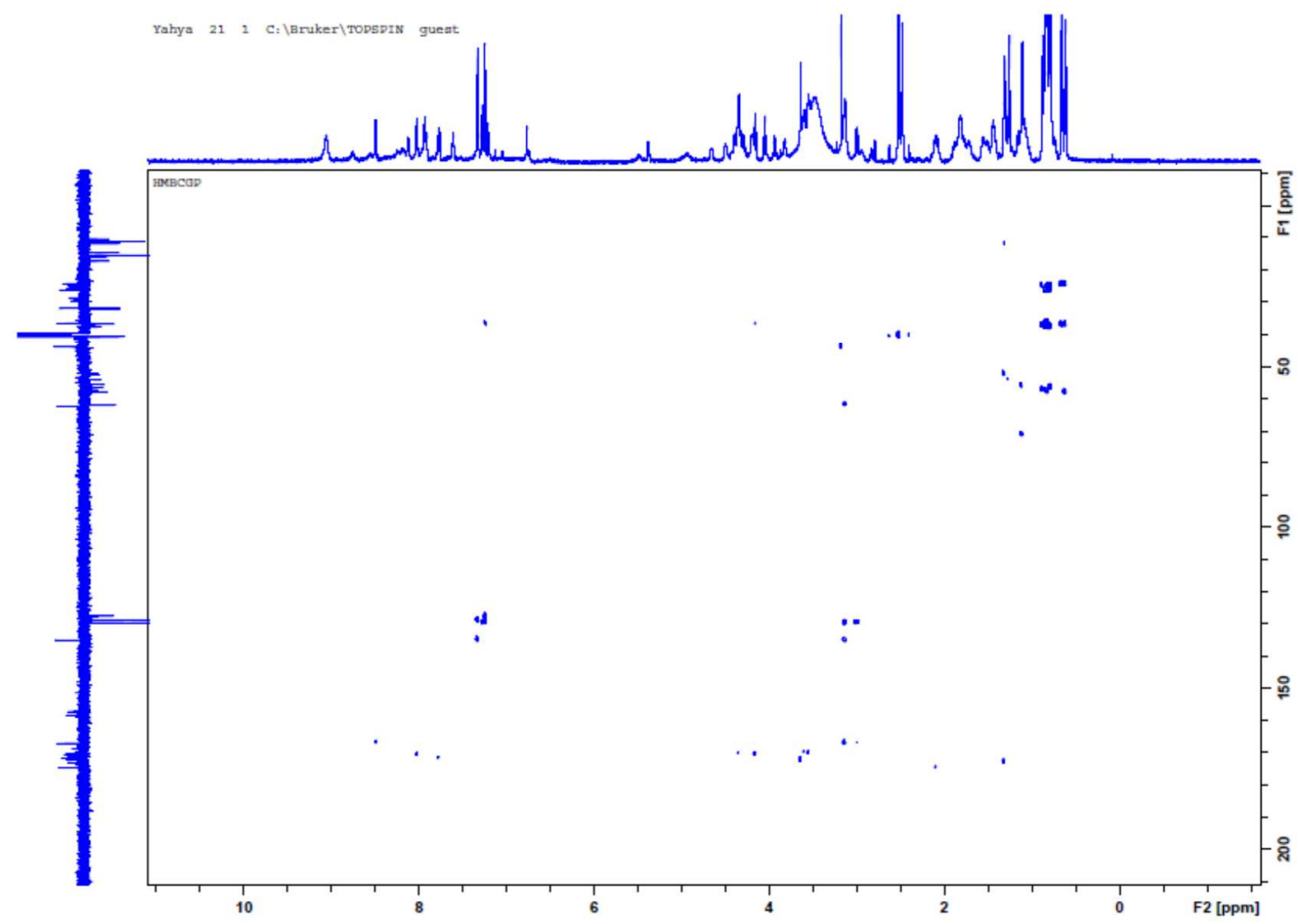




\section{Biological activity}

\section{Compounds and Reference bacterial strains}

The compound was dissolved in sterile distilled water. The ATCC bacterial strains (2 Gram positive and 2 Gram negative) were subcultured onto Mueller Hinton agar and incubated at $37^{\circ} \mathrm{C}$ for 24 hours prior to use in the experiments.

\section{Minimum Inhibitory Concentration (MIC) determination}

The MIC was determined using the broth microdilution method as described by the Clinical and Laboratory Standards Institute (CLSI) guidelines. ${ }^{3}$ Briefly, two-fold serial dilutions of each drug/compound were done in cation adjusted Mueller Hinton broth (CAMHB) in a 96 well microtitre plate. The bacterial inoculum was prepared in distilled water and matched to a $0.5 \mathrm{McF}$ arland standard and added to make a final volume of $200 \mu \mathrm{l}$ in each microtitre well. The plates were incubated for 24 hours at $37{ }^{\circ} \mathrm{C}$ under aerobic conditions. The MIC was then recorded, as the lowest concentration at which there was no visible growth. A drug free and media control wells containing bacteria and CAMHB respectively were included in each plate. Meropenem was also tested as drug control. The assay was done in duplicate to confirm results.

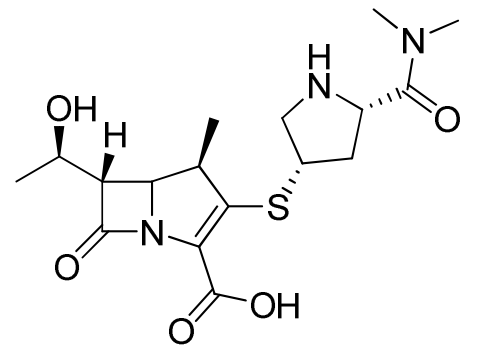

Meropenem

1. De Vleeschouwer, M.; Sinnaeve, D.; Van den Begin, J.; Coenye, T.; Martins, J. C.; Madder, A., Chem.--Eur. J. 2014, 20, 7766-7775.

2. $\quad$ Ling, L. L.; Schneider, T.; Peoples, A. J.; Spoering, A. L.; Engels, I.; Conlon, B. P.; Mueller, A.; Schaberle, T. F.; Hughes, D. E.; Epstein, S.; Jones, M.; Lazarides, L.; Steadman, V. A.; Cohen, D. R.; Felix, C. R.; Fetterman, K. A.; Millett, W. P.; Nitti, A. G.; Zullo, A. M.; Chen, C.; Lewis, K., Nature 2015, 517, 455-459.

3. Clinical and Laboratory Standards Institute, 2012. Methods for dilution antimicrobial susceptibility tests for bacteria that grow aerobically; approved standard 8th ed. CLSI publication M07-A9. Clinical Laboratory Standard Institute, Wayne, PA. 